\title{
Techniques for Estimating Peak Flow on Small Streams in Minnesota
}

By David L. Lorenz, George H. Carlson, and Chris A. Sanocki

U.S. Geological Survey

Water-Resources Investigations Report 97-4249

Prepared in cooperation with the

Minnesota Department of Transportation 


\section{U.S. DEPARTMENT OF THE INTERIOR \\ BRUCE BABBITT, Secretary \\ U.S. GEOLOGICAL SURVEY \\ Mark Schaefer, Acting Director}

For additional information write to:

District Chief

U.S. Geological Survey

2280 Woodale Drive

Mounds View, MN 55112
Copies of this report can be purchased from:

U.S. Geological Survey

Branch of Information Services

Box 25286

Denver, Colorado 80225-0286 


\section{CONTENTS}

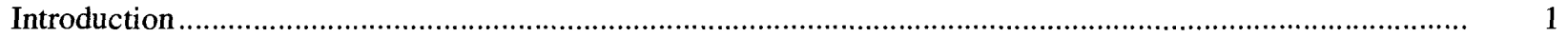

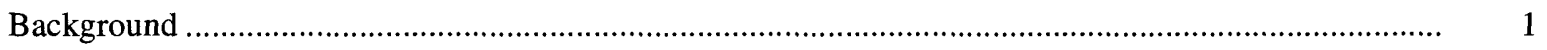

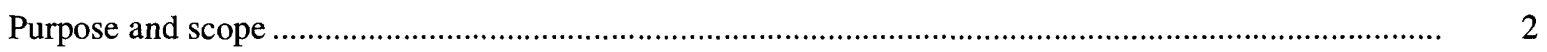

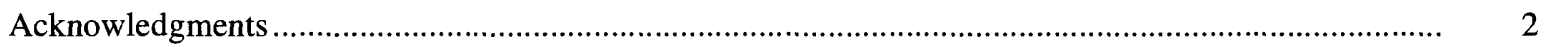

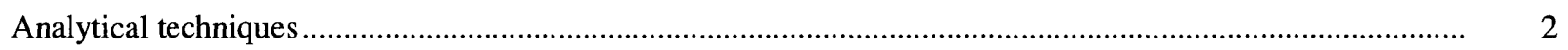

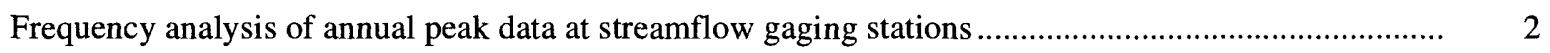

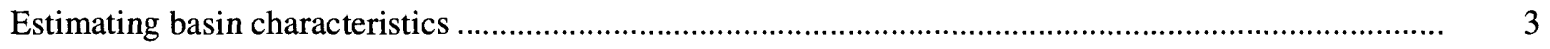

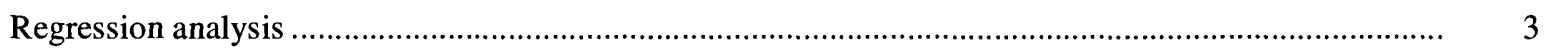

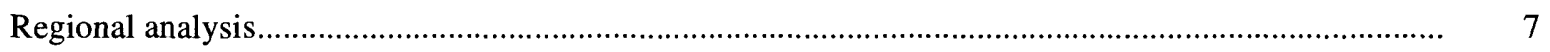

Techniques for estimating peak flow on small streams in Minnesota ........................................................ 7

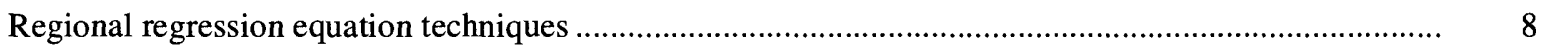

Region of influence regression technique ................................................................................. 8

Comparison of regional regression equation and region of influence regression techniques .................... 10

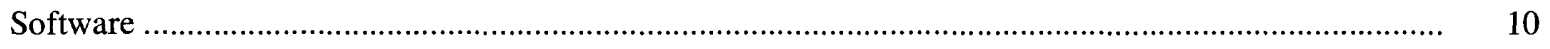

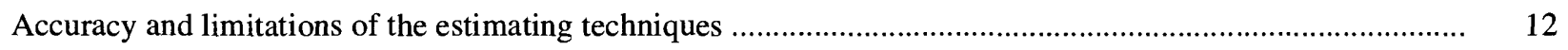

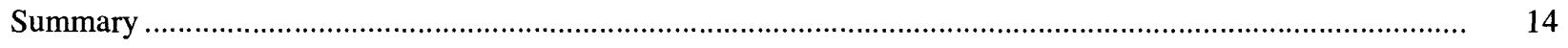

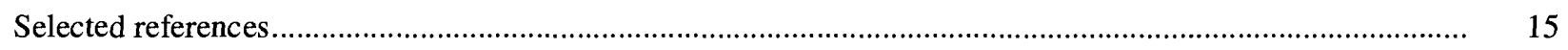

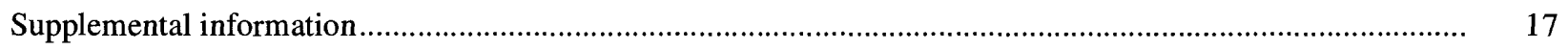

Figures 1-2. Map showing:

1. Location of streamflow-gaging stations and regions for estimating peak flow ..................................... 5

2. Generalized mean annual runoff in Minnesota, 1951-85 .......................................................................

Figure 3. Graph showing distance between streamflow gaging stations and peak-flow cross correlation in Minnesota.

\section{TABLES}

Table 1. Peak-flow frequency data for streamflow gaging stations......................................................... 19

2. Basin characteristics for streamflow gaging stations ................................................................. 30

3. Prediction equations, standard errors of the estimate, and the equivalent years of record ............... 9

4. PRESS/n statistics for each region and recurrence interval ........................................................ 11

5. Upper and lower values and geometric mean of the independent variables used in the regional regression analysis of each region 


\section{CONVERSION FACTORS}

$\begin{array}{lcl}\text { Multiply } & \text { by } & \text { To obtain } \\ \text { inch (in.) } & 25.4 & \text { millimeter } \\ \text { square mile (mi2) } & 2.590 & \text { square kilometer } \\ \text { foot(ft) } & .3048 & \text { meter } \\ \text { cubic foot per second (ft3/s) } & .02832 & \text { cubic meter per second }\end{array}$

Use of trade, product, or firm names in this report are for identification purposes only and does not constitute endorsement by the U.S. Geological Survey. 


\title{
Techniques for estimating peak flow on small streams in Minnesota
}

\author{
by D.L. Lorenz, G.H. Carlson, and C.A. Sanocki
}

\begin{abstract}
Two statistically-derived techniques, regional regression equation and region of influence regression, that estimate peak flow on small, ungaged streams in Minnesota were developed. Both techniques relate physical and climatic characteristics to peak flow for 2-, 5-, 10-, 25-, 50-, and 100-year recurrence intervals.
\end{abstract}

Regional regression equations were developed for each recurrence interval in each of six regions in Minnesota. The region of influence regression technique dynamically selects stations with characteristics similar to a site of interest. Thus, the region of influence regression technique allows use of a potentially unique set of stations for estimating peak flow at each site of interest. Two methods of selecting streamflow gaging stations, similarity and proximity, are recommended for use in the region of influence regression technique.

The regional regression equation technique is recommended as a first estimate of peak flow in regions $\mathrm{C}$, $\mathrm{E}$, and $\mathrm{F}$. The similarity method of the region of influence regression technique should be used as a first estimate in regions $\mathrm{A}$ and $\mathrm{D}$. The proximity method should be used as a first estimate in region $\mathrm{B}$.

Tables showing the peak-flow-frequency data and basin characteristics for streamflow gaging stations, and regional peak-flow prediction equations, are documented.

\section{INTRODUCTION}

Knowledge of the peak flow of floods of a given recurrence interval is essential for regulation and planning of water resources and bridge, culvert, and dam design along Minnesota's rivers and streams. Techniques are needed to estimate peak flow at ungaged sites because long-term streamflow records are available at relatively few places.

This report is one of a series of reports prepared in cooperation with the Minnesota Department of Transportation that discuss peak-flow frequency on small streams. This report supersedes previous reports by Prior (1949), Prior and Hess (1961), Wiitala (1965), Patterson and Gamble (1968), Guetzkow (1977), and Jacques and Lorenz (1987); all of which dealt with techniques for estimating peak flow in Minnesota. Analysis of annual peakflow records for the first of these reports that employed the Log Pearson Type III method of analysis (Guetzkow, 1977) may not have included historical flood information in the analysis, and the period of record for many small streams was very short from the standpoint of flood history. Most of the long-term record stations included the low annual peaks from the 1930's drought and high annual peaks during the 1950's and 1960's.
Historical flood information was incorporated in the analysis done by Jacques and Lorenz (1987). Jacques and Lorenz (1987) also used fewer regions than Guetzkow (1977), which resulted in larger standard errors of estimate for the regional equations.

\section{Background}

Continuous daily records for streamflow gaging stations in Minnesota span a relatively short time period. The longest record is for the Mississippi River at St. Paul, which is continuous from 1867 to present, except for 1871. Gaging of several streams to obtain daily streamflow records was started about 1909. The number of streamflow gaging stations decreased between 1912 and 1920. During the late 1920's and early 1930's, the number of streamflow gaging stations increased. Many of those streamflow gaging stations presently are in operation. Over the years, streamflow gaging stations were added where flow information was needed, and other stations were discontinued where additional data were not needed. Streamflow gaging stations operated to obtain daily records generally are located on streams that drain areas greater than $300 \mathrm{mi}^{2}$ and flow continuously. 
In the 1950's, planners for the interstate highway system learned that little information was available about peak flow on small streams. This information was needed for determining the necessary size of bridges and culverts at road crossings. As a result of this need, small-stream flood investigation projects were initiated nationwide. The program in Minnesota began in 1958 and over the next 6 years about 150 streamflow gaging stations were established to determine annual peak flow and stage on streams draining about $60 \mathrm{mi}^{2}$ or less. Most of those stations were operated through the 1970's. In the 1980's, gaging for annual peak flow and stage for most of the drainage basins of less than $10 \mathrm{mi}^{2}$ was discontinued. Some new peak-flow gaging stations recently were established on streams draining areas from $10 \mathrm{mi}^{2}$ to several hundred square miles.

\section{Purpose and scope}

This report (1) documents the analytical techniques used for annual series peak-flowfrequency computations, basin characterization, regionalization, and development of equations for estimating peak flow on small drainage basins; (2) presents peak-flow data and basin characteristics at streamflow gaging stations; and (3) discusses techniques for estimating peak flow at ungaged sites on small, unregulated streams in Minnesota.

Streamflow gaging stations on the Red Lake, Minnesota, Mississippi, Rainy, St. Louis, and Red River of the North Rivers that have drainage areas greater than $5,000 \mathrm{mi}^{2}$, were not included in this analysis. Other streamflow gaging stations that were not included in this analysis had peak flows that were affected by controlled storage or regulated releases.

\section{Acknowledgments}

The authors thank Steven K. Sando and David Eash, of the U.S. Geological Survey, for providing basin characteristics and peak flow analyses of streamflow gaging stations in South Dakota and Iowa. We thank Gary Tasker, of the U.S. Geological Survey, for his assistance in statistical analysis.

\section{ANALYTICAL TECHNIQUES}

This section describes the analytical techniques and adjustments to analyses that were required to develop the techniques for estimating the peak flow on small streams. It also presents preliminary computations required for regression analysis.

\section{Frequency analysis of annual peak flow data at streamflow gaging stations}

An annual series peak-flow-frequency analysis at each streamflow gaging station (fig. 1) was prepared according to the procedures outlined in Bulletin 17B (U.S. Water Resources Council, 1982).

Many more streamflow gaging stations that have at least 25 years of record are available now than when the skew map of Bulletin 17B (U.S. Water Resources Council, 1982) was developed. Therefore, before computations of peak-flow frequency were begun, stations with 25 or more years of record in and near Minnesota were analyzed to determine the station skew coefficient and an updated generalized skew coefficient map was prepared and published (Lorenz, 1997). The resultant generalized skew coefficients were used in the Log-Pearson Type III peak-flow-frequency analysis used for this report.

Treatment of discontinuous periods of record (also called broken record) and the occurrence of large floods either within or outside the period of record, and considered "historic", are described below.

1. Where the record is not continuous and there is no indication of a historic flood, the record has been treated as though it was a continuous homogeneous record.

2. Where the flow of a large flood that occurred several years before the start of the record of annual peak flows is known, and that flood flow has not been exceeded, a historic period extending from the year of the large flood to 1995, or to the end of annual peak data, was used in the peak-flow frequency computation. For some streams where the record ended prior to 1995, and the large, historic flood flow has not been exceeded since the end of the record, the historic period was extended to 1995 , if that extension improved the agreement between the observed peaks and the peak-flowfrequency analysis.

3. Where a large flood occurred before the start of the record of annual peak flows, but the flow is not known, the record was analyzed with a corresponding historic period if the record 
contained a high outlier, as defined by U.S. Water Resources Council, 1982. If possible, that result was compared to peak-flow frequency analysis of nearby stations to support the valid use of the historic period.

4. Where the record was continuous for at least 50 years and there was a very large flood flow in the record, and there was evidence of a large regional flood outside of the period of record, the record was analyzed with and without use of a historic period. The results of both analyses were compared to the station data and the peak-flow frequency analysis of nearby stations, if possible. The analysis using the historic period was used if the comparison justified it.

The peak-flow frequency computations for streamflow gaging stations outside of Minnesota were obtained from a U.S. Gelogical Survey (USGS) office of the given state. The peak-flow frequency computations are listed table 1 (in the Supplemental Information at the end of this report).

\section{Estimating basin characteristics}

Fourteen reports published by the USGS describe basin characteristics for gaged streams in the Minnesota and Crow River Basins (southern part of Minnesota). These reports list the drainage area, percent of the drainage area covered by lakes, percent drainage area covered by lakes and wetlands (storage), main-channel length, and mainchannel slope.

For other gaged streams in Minnesota, drainage area boundaries were delineated on the basis of topographic contours and anthropogenic alterations to the landscape. Those alterations, such as the installation of storm sewers, the drainage of wetlands, and the diversion of streams can change the drainage area of a stream. Drainage basin delineation was done by the USGS, the Minnesota Department of Natural Resources Division of Waters, and Mankato State University Water Resources Center. Drainage area boundaries were drawn on USGS 1:24,000 topographic maps. The drainage area boundaries were digitized or scanned by the Minnesota Department of Natural

Resources, Minnesota State Planning Land Management Information Center, Mankato State University, and the USGS and transferred to a geographic information system (GIS). The Canada Centre For Mapping, Department of Energy, Mines and Resources Canada 1:50,000 topographic maps were used to obtain subbasin boundaries, mainchannel length, contour elevation points, area of lakes, and area of wetlands within Canada.

Lake and wetland data were obtained from the U.S. Fish and Wildlife Service National Wetlands Inventory (NWI). NWI data were extracted for each gaging station to identify the percentage of lake and percentage of storage (lake and wetland) area in the basin represented by each streamflow gaging station. The total area of lakes and wetlands in the basin represented by each streamflow gaging station was calculated using the GIS.

Main channels were defined from Basemap '97 (Minnesota Department of Transportation, 1997). Basemap ' 97 is a basic core of geographic data that cover the state of Minnesota. Extensions to the main channel through lakes and from the end of the mapped stream line to an endpoint within the drainage basin, generally at the divide, were added to the Basemap '97 data.

Elevations of intersections of topographic contour lines and main channels were digitized using the GIS. Two points on the main channel, at 10 percent and at 85 percent of the main-channel length from the streamflow gaging station to the endpoint of the extension, were located by the GIS. The elevations of these two points were interpolated from digitized elevation data. Mainchannel slope was calculated by dividing the difference in elevation between those points by the distance along the main channel between those points.

The generalized runoff was based on the map of Gebert and others (1985) (fig. 2). The value of the generalized runoff for the basin was determined from the streamflow gaging station location using the surface interpolation function by Akima (1978). The basin characteristics are listed in table 2 (in the Supplemental Information section at the end of this report).

\section{Regression analysis}

Tasker and others (1986) described the use of the generalized least squares (GLS) technique to estimate 100-year peak flow for an area in Arizona. They showed that the technique provided better estimates than the ordinary least squares technique. The GLS technique accounts for cross-correlated peak-flow data between stations having concurrent record. It also accounts for variance in estimated peak flow at each streamflow gaging station 


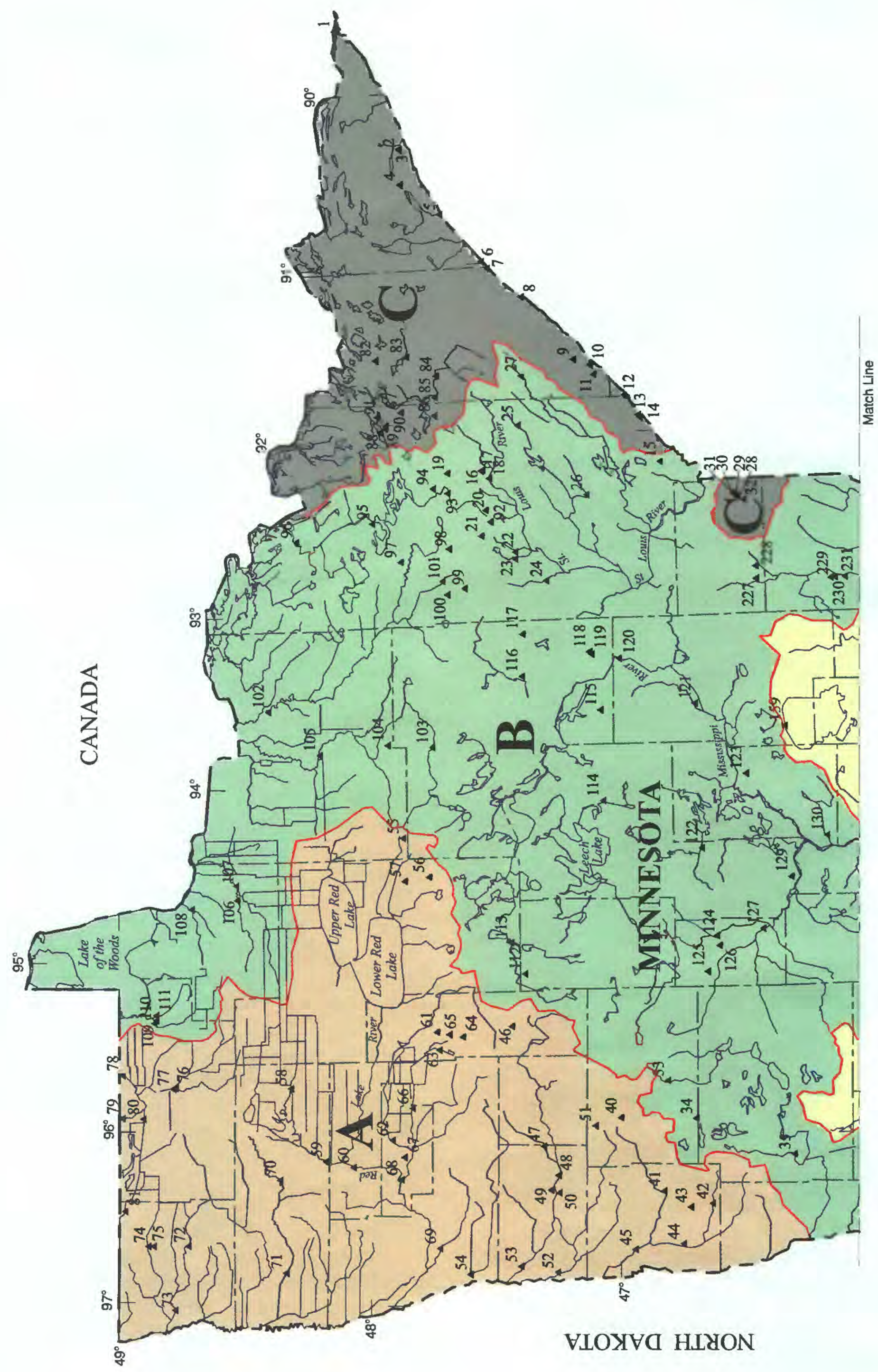




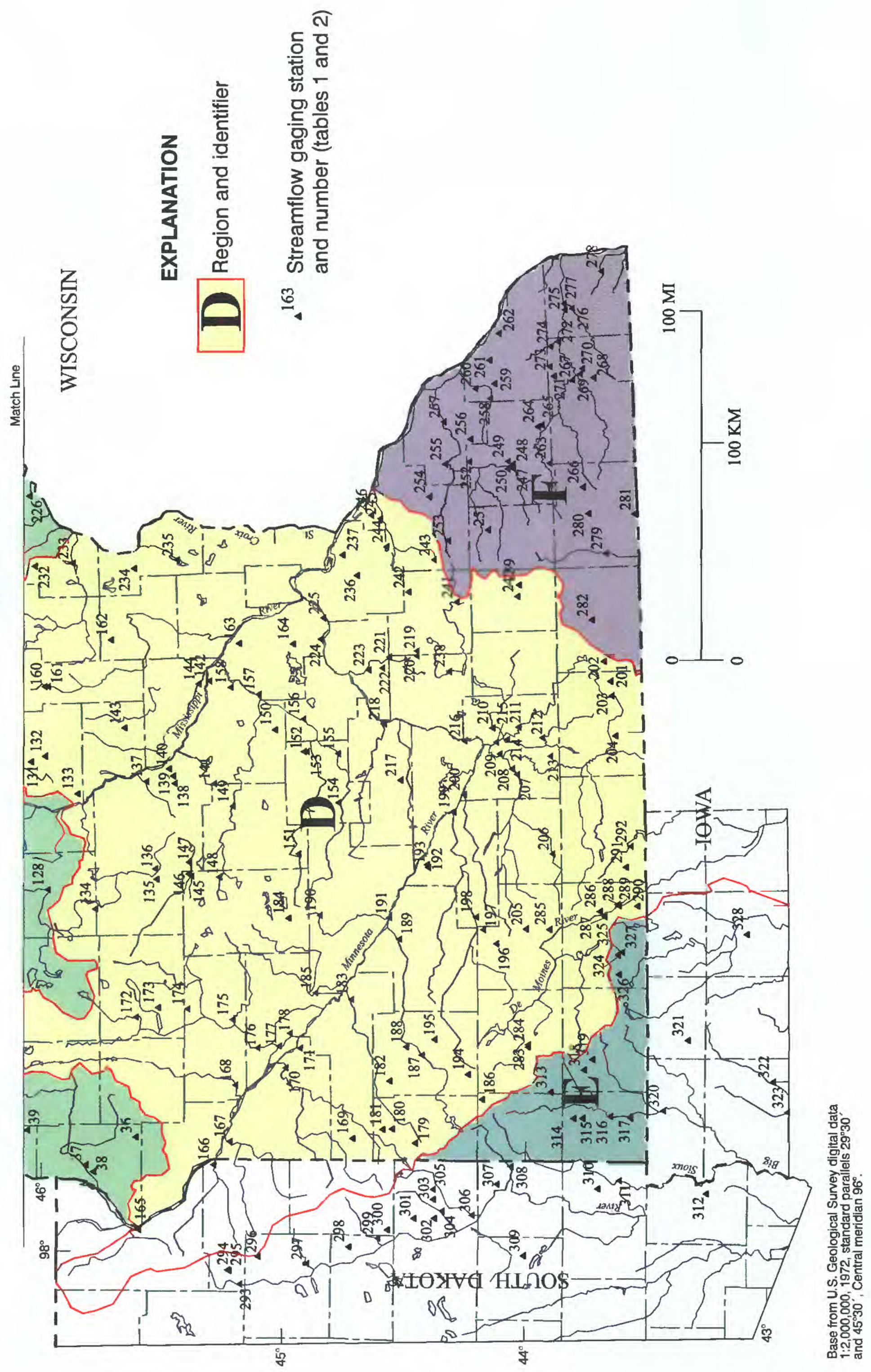

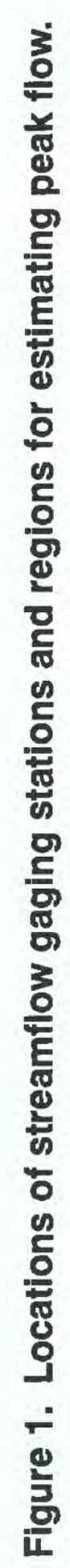




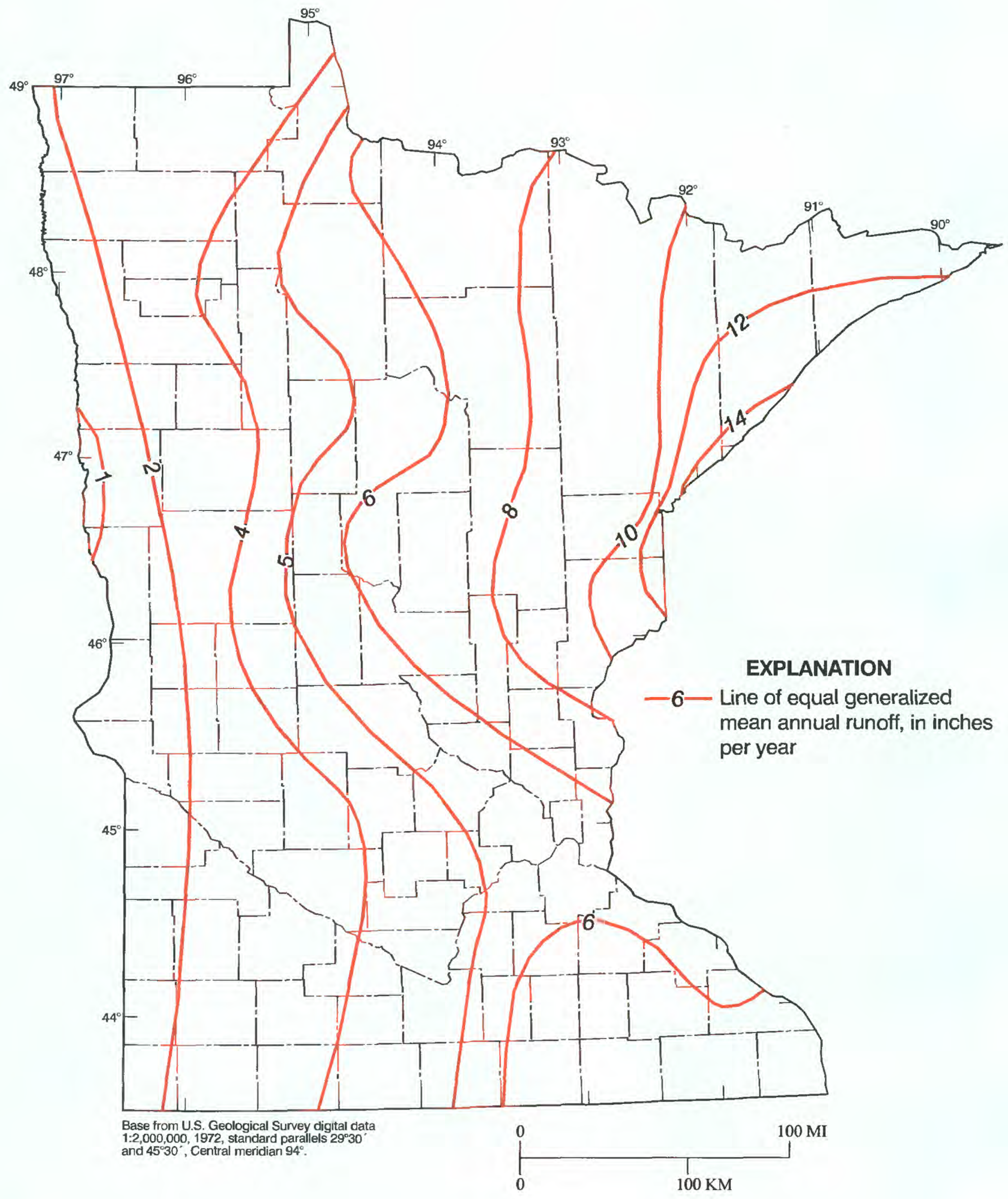

Figure 2. Generalized mean annual runoff in Minnesota, 1951-85 [modified from Gebert and others, 1985]. 
because of the difference in record length. Cross correlation is the correlation between peak flow at two different streamflow gaging stations as a result of similar weather patterns affecting those stations. In ordinary least squares regression, crosscorrelated peak-flow data decrease the effective amount of information in an analysis and can contribute to errors in predictive precision (model error) and errors in determination of the coefficients of the independent variables (Stedinger and Tasker, 1985).

The GLS technique requires a reasonable estimate of the cross correlation between flows at every pair of stations (Tasker and Stedinger, 1989). An estimate based on the measured flows is not reliable because of the short concurrent records usually encountered in peak-flow data. Therefore, sample cross correlations are estimated by relating the distance between each pair of stations to the correlation between peak flows. Stations with at least 25 years of record were selected for the analysis of cross correlation and distance. From these stations, there were 9,735 pairs of correlations where there were at least 25 years of concurrent record. These 9,735 data pairs were reduced to 152 using the following two steps. First, the data were sorted by distance. Second, the mean distance and mean correlation, both weighted by concurrent record length, were computed for each sequential group of 64 data points. These 152 pairs of reduced data were used in a nonlinear regression analysis to relate cross correlation to distance. These data are shown in figure 3 . These data summarize the trend of the entire data set, but do not represent the true scatter of the original data. The nonlinear regression equation relating cross correlation to distance is as follows:

$$
\rho(i, j)=0.6314-0.4062 * \operatorname{atan}(\operatorname{dist}(i, j) / 92.27),
$$

where

$\rho(i, j)=$ the estimated cross correlation between stations $i$ and $j$,

$\operatorname{atan}(\mathrm{x})=$ the $\operatorname{arctangent}$ of $\mathrm{x}$, and $\operatorname{dist}(i, j)=$ the distance, in miles, between stations $i$ and $j$.

The equation is valid for $i$ not equal to $j$; for $i$ equal to $j$, the cross correlation is 1 .

Step-backward selection is used for selecting variables in the regression models. The selection process begins by calculating statistics for all independent variables. Then variables are deleted from the model if the coefficient has the incorrect sign or if the T-score is less than 1.7. At each step, the variable having the lowest T-score is deleted.

\section{Regional analysis}

The regions for estimating peak flow shown on figure 1 were modified from those in Jacques and Lorenz (1987). The regions defined in that report formed the basis for formation of new regions described in this report. Regional regression equations were developed for the regions defined by Jacques and Lorenz (1987). The residuals of peak-flow values associated with the regressions were examined in a two-step process. In the first step, the residuals from each regional regression were examined for a subregional pattern. If a subregional pattern was evident, that subregion was removed from the original region. In the second step, the residuals were examined to verify a normal, homoscedastic distribution. If the residuals were approximately normally distributed and homoscedastic, the region was accepted; otherwise, the region was subdivided again and the second step was repeated from this two-step process, two new regions, $\mathrm{E}$ and $\mathrm{F}$, were identified and regions $\mathrm{B}$ and $\mathrm{C}$ were slightly modified. The average standard error of the estimate (SEE), discussed in the Accuracy and Limitations of the Estimating Techniques section, decreased from 51 percent for old region $D$ to an average 47 percent for new regions $\mathrm{D}, \mathrm{E}$, and $\mathrm{F}$.

Regional boundaries are shown on figure 1 . Table 3 includes the number of streamflow gaging stations in each region. The regional boundaries follow drainage divides so that the drainage basin of a small stream will not overlap two regions, making interpretation easier for all small streams.

\section{TECHNIQUES FOR ESTIMATING PEAK FLOW ON SMALL STREAMS IN MINNESOTA}

This section presents two statistically-derived techniques for estimating peak flows on small, ungaged streams in Minnesota. Both of the techniques relate physical and climatic characteristics to peak flows for 2-, 5-, 10-, 25-, $50-$, and 100-year recurrence intervals. 


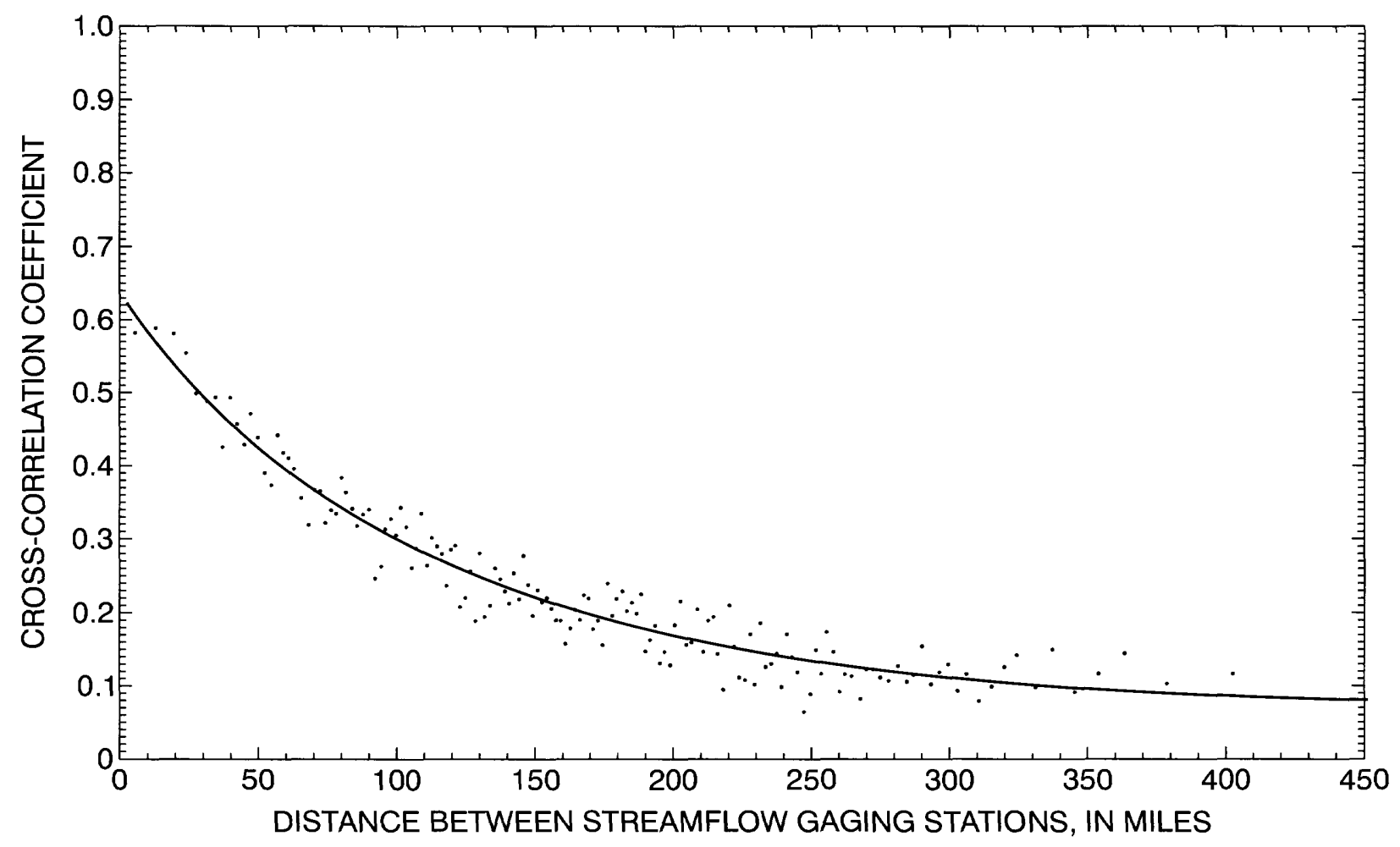

Figure 3. Distance between streamflow gaging stations and peak-flow cross correlation in Minnesota.

Regional regression equation technique

Regression equations were developed for each recurrence interval and for each region shown on figure 1. Table 3 presents those equations, the SEE and the equivalent years of record discussed in the Accuracy and Limitations of the Estimating Techniques section. The SEE is included for comparison to previous regional regression equations.

\section{Region of influence regression technique}

The fundamental premise of the region of influence regression (ROI) technique is that there is no need for distinct boundaries between regions (Burn, 1990). Each region is defined by selecting streamflow gaging stations with characteristics that are similar to the site of interest. Thus, the ROI technique allows use of a potentially unique set of streamflow gaging stations for each site of interest. Two methods are available for this technique. The similarity method selects streamflow gaging stations that have similar characteristics (variables). The proximity method selects streamflow gaging stations that are nearby.
The ROI technique requires the selection of a distance metric defining the similarity of each streamflow gaging station to the site of interest. Similarity is defined in terms of shortest distance. An appropriate metric is the weighted Euclidean distance in M-dimensional space (Burn, 1990). The distance metric is defined:

$$
D(i)=\sqrt{\sum_{m=1}^{M}\left[W(m) \times(X(m, i)-X(m))^{2}\right]},
$$

where

$D(i)=$ the distance from station $i$ to the site of interest,

$W(m)=$ the weight applied to variable $m$,

$X(m, i)=$ the value of attribute $m$ for station $i$, and $X(m)=$ the value of the attribute for the site of interest.

In most cases, the weight for each attribute is the reciprocal of the variance of the attribute, computed from the values at all streamflow gaging stations. This technique selects a certain number, 36 for this study, of streamflow gaging stations 
Table 3.--Regression equations, standard errors of the estimate, and the equivalent years of record. [SEE, standard error of the estimate; EY, equivalent years of record; DA, drainage area, in square miles; ST, storage, in percent of drainage area; LK, area covered by lakes, in percent of drainage area; RO, generalized runoff, in inches; SL, slope, in feet per mile. Number in parentheses following region is number of streamflow gaging stations used to develop the equation.]

\begin{tabular}{|c|c|c|}
\hline Regression equation & $\underset{\text { (percent) }}{\mathrm{SEE}}$ & EY \\
\hline \multicolumn{3}{|c|}{ REGION A (42) } \\
\hline $\mathrm{Q} 2=22.2 \mathrm{DA}^{0.667}(\mathrm{ST}+1)^{-0.076}(\mathrm{LK}+1)^{-0.121}$ & 40 & 4.7 \\
\hline $\mathrm{Q} 5=49.7 \mathrm{DA}^{0.680}(\mathrm{ST}+1)^{-0.136}(\mathrm{LK}+1)^{-0.186}$ & 36 & 7.5 \\
\hline $\mathrm{Q} 10=75.2 \mathrm{DA}^{0.682}(\mathrm{ST}+1)^{-0.168}(\mathrm{LK}+1)^{-0.208}$ & 37 & 9.9 \\
\hline $\mathrm{Q} 25=116 . \mathrm{DA}^{0.681}(\mathrm{ST}+1)^{-0.205}(\mathrm{LK}+1)^{-0.223}$ & 39 & 12.4 \\
\hline $\mathrm{Q} 50=154 . \mathrm{DA}{ }^{0.678}(\mathrm{ST}+1)^{-0.230}(\mathrm{LK}+1)^{-0.228}$ & 41 & 13.6 \\
\hline $\mathrm{Q} 100=197 . \mathrm{DA}^{0.675}(\mathrm{ST}+1)^{-0.252}(\mathrm{LK}+1)^{-0.231}$ & 44 & 14.5 \\
\hline
\end{tabular}

REGION B (59)

$\mathrm{Q} 2=5.16 \mathrm{DA}^{0.820}(\mathrm{ST}+1)^{-0.136}(\mathrm{LK}+1)^{-0.400} \mathrm{RO}^{0.859}$

$\mathrm{Q} 5=15.2 \mathrm{DA}^{0.818}(\mathrm{ST}+1)^{-0.170}(\mathrm{LK}+1)^{-0.479} \mathrm{RO}^{0.667}$

$\mathrm{Q} 10=26.0 \mathrm{DA}^{0.818}(\mathrm{ST}+1)^{-0.195}(\mathrm{LK}+1)^{-0.515} \mathrm{RO}^{0.590}$

2.8

$\mathrm{Q} 25=44.9 \mathrm{DA}^{0.818}(\mathrm{ST}+1)^{-0.228}(\mathrm{LK}+1)^{-0.550} \mathrm{RO}^{0.523}$

3.4

$\mathrm{Q} 50=63.2 \mathrm{DA}^{0.818}(\mathrm{ST}+1)^{-0.252}(\mathrm{LK}+1)^{-0.570} \mathrm{RO}^{0.489}$

4.1

43

5.2

$\mathrm{Q} 100=85.4 \mathrm{DA}^{0.818}(\mathrm{ST}+1)^{-0.276}(\mathrm{LK}+1)^{-0.587} \mathrm{RO}^{0.464}$

6.0

47

6.7

REGION C (29)

$\mathrm{Q} 2=34.6 \mathrm{DA}^{0.961} \mathrm{SL}^{0.359}(\mathrm{ST}+1)^{-0.532}(\mathrm{LK}+1)^{-0.280}$

$\mathrm{Q} 5=64.5 \mathrm{DA}^{0.928} \mathrm{SL}^{0.387}(\mathrm{ST}+1)^{-0.561}(\mathrm{LK}+1)^{-0.314}$

$\mathrm{Q} 10=81.4 \mathrm{DA}^{0.913} \mathrm{SL}^{0.425}(\mathrm{ST}+1)^{-0.567}(\mathrm{LK}+1)^{-0.328}$

$\mathrm{Q} 25=97.6 \mathrm{DA}^{0.898} \mathrm{SL}^{0.481}(\mathrm{ST}+1)^{-0.569}(\mathrm{LK}+1)^{-0.342}$

$\mathrm{Q} 50=106 . \mathrm{DA}^{0.890} \mathrm{SL}^{0.527}(\mathrm{ST}+1)^{-0.569}(\mathrm{LK}+1)^{-0.350}$

$\mathrm{Q} 100=112 . \mathrm{DA}^{0.883} \mathrm{SL}{ }^{0.574}(\mathrm{ST}+1)^{-0.567}(\mathrm{LK}+1)^{-0.356}$

REGION D (126)

$\mathrm{Q} 2=7.15 \mathrm{DA}^{0.796} \mathrm{SL}^{0.449}(\mathrm{LK}+1)^{-0.401}$

$\mathrm{Q} 5=14.1 \mathrm{DA}^{0.796} \mathrm{SL}^{0.475}(\mathrm{LK}+1)^{-0.411}$

$\mathrm{Q} 10=19.8 \mathrm{DA}^{0.794} \mathrm{SL}^{0.488}(\mathrm{LK}+1)^{-0.414}$

$\mathrm{Q} 25=28.2 \mathrm{DA}^{0.792} \mathrm{SL}^{0.503}(\mathrm{LK}+1)^{-0.416}$

$\mathrm{Q} 50=35.1 \mathrm{DA}^{0.791} \mathrm{SL}^{0.513}(\mathrm{LK}+1)^{-0.416}$

$\mathrm{Q} 100=42.5 \mathrm{DA}^{0.790} \mathrm{SL}^{0.522}(\mathrm{LK}+1)^{-0.416}$

$\mathrm{Q} 2=1.84 \mathrm{DA}^{0.848} \mathrm{SL}^{0.758} \mathrm{RO}^{0.690}$

$\mathrm{Q} 5=6.12 \mathrm{DA}^{0.826} \mathrm{SL}^{0.721} \mathrm{RO}^{0.647}$

$\mathrm{Q} 10=10.8 \mathrm{DA}^{0.821} \mathrm{SL}^{0.706} \mathrm{RO}^{0.644}$

$\mathrm{Q} 25=18.4 \mathrm{DA}^{0.823} \mathrm{SL}^{0.698} \mathrm{RO}^{0.655}$

$\mathrm{Q} 50=25.0 \mathrm{DA}^{0.828} \mathrm{SL}^{0.697} \mathrm{RO}^{0.670}$

$\mathrm{Q} 100=32.2 \mathrm{DA}^{0.834} \mathrm{SL}^{0.699} \mathrm{RO}^{0.686}$

$\mathrm{Q} 2=37.6 \mathrm{DA}^{0.712} \mathrm{SL}^{0.223}$

$\mathrm{Q} 5=55.3 \mathrm{DA}^{0.718} \mathrm{SL}^{0.317}$

$\mathrm{Q} 10=66.7 \mathrm{DA}^{0.721} \mathrm{SL}^{0.367}$

$\mathrm{Q}^{25}=79.7 \mathrm{DA}^{0.723} \mathrm{SL}^{0.425}$

$\mathrm{Q} 50=87.9 \mathrm{DA}^{0.724} \mathrm{SL}^{0.466}$

$\mathrm{Q} 100=94.9 \mathrm{DA}^{0.725} \mathrm{SL}^{0.505}$
4.4

5.4

6.0

6.5
3.4

5.7

7.5

9.3

10.3

10.9

REGION E (36)

5.0

10.8

18.4

33.7

50.4

71.8

REGION F (36)

5.3
10.1
15.2
21.4
24.6
26.3


closest to the site of interest to represent the region. For this study, slope, percent storage, percent lake area, and generalized runoff were used to define the region of influence for the similarity method. These variables vary regionally across Minnesota to a certain extent. Drainage area is not included in the selection variables because the correlation between drainage area, slope, percent storage and percent lakes does restrict the range of drainage basin areas when the other variables are included.

An alternative to the similarity method is the proximity method, in which the distance metric is defined as the actual distance, in miles for example, between the site of interest and streamflow gaging stations. In the proximity method, the weight of variables is not considered. This method assumes that the region of influence is determined from a gradient of climatic and physiographic factors that are best represented by location and that those factors are not necessarily limited to the independent variables selected for this analysis.

The trade-off between the similarity method and the proximity method is in the cross correlation between the streamflow gaging stations selected in the region of influence. Stations selected using the proximity method probably will have a higher cross correlation than stations selected using the similarity method. The higher cross correlation reduces the effective amount of information for the region and can make the regression equations appear more accurate than they are when comparing predicted and measured peak flows. The average cross-correlation coefficient was 0.09 for the similarity method and 0.13 for the proximity method in Minnesota. These average cross-correlation coefficient values for the two methods were not substantially different.

\section{Comparison of regional regression equation and region of influence regression techniques}

One method for comparing the regional regression equation technique and the region of influence regression technique is to use the PRESS/n statistic, which is the mean Prediction Error Sum of Squares. The PRESS/n statistic is determined by removing each site (of $\mathbf{n}$ sites) from the analysis, re-developing the prediction equations, and comparing the predicted peak-flow value to the measured value for that site in a region. The differences between the predicted and measured values are squared and the mean for all sites is computed. That way, $\mathrm{n}$ analyses are made without the predicted site being included. It is a reasonably unbiased comparison if the sites are not highly cross correlated.

Table 4 is a listing of the PRESS/n statistics for each region and recurrence interval. The minimum mean PRESS/n statistic indicates the preferred technique for each region. However, for region C, because the difference between the PRESS/n for the regional regression equation and the proximity method of ROI is only 0.0001 and the individual PRESS/n statistics for each recurrence interval greater than 5 years is less for the regional regression equation; that technique is preferred for that region. For the other regions, the proximity method is preferred for region $\mathrm{B}$, the similarity method for regions $A$ and $D$, the regional regression equations for regions $\mathrm{E}$ and $\mathrm{F}$.

Regional regression appears strongly preferable for region $\mathrm{E}$ because the mean PRESS/n statistics for the ROI methods are so much higher than those for the regional regression equation. For the other regions, all methods might be given some consideration in evaluating the peak flow for a given recurrence interval.

\section{Software}

A software packet is included with this report. It is a 3.5-inch floppy disk that contains the program and data files to run the regional regression equations and the region of influence regression techniques. The program is for use on an MSDOS operating system (version 3.0 or higher) and requires a math co-processor.

The software can be installed on any computer system using the MSDOS operating system. The steps for installing the software are as follows.

\section{Open a MSDOS window if using any window} system.

2. Insert the floppy disk into drive a:.

3. Type "a:install c: Ipeakflow", where c: Ipeakflow is the desired directory to install the software.

4. Two versions of the executable are included. The version called pf16.exe will run on any MSDOS computer. The version called pf32.exe will only run on a computer that supports a 32-bit operating system (Windows 95 or newer). 
5. To run the program, change directory to c: Ipeakflow and type pf 32 or pf 16 , whichever is appropriate for the system.

The program requires the user to enter an output file name; select a technique, either RRE for regional regression equations or RO1 for region of influence regression; enter a site identifier; and enter the necessary basin characteristics. For the RRE technique, only those basin characteristics necessary for the equation are entered. For the RO1 technique, drainage area, main-channel slope, area of storage, area of lakes, and generalized runoff must be entered. For the RO1 technique, the user must specify a selection method, usually $\mathrm{P}$ for proximity or $\mathrm{S}$ for similarity. Multiple analyses for any number of stations or techniques can be performed during a single session.

An example of the dialogue from the program is shown in the Supplemental lnformation section, with informative messages in normal font, program prompts in italics, and user input in bold. The dialogue includes an example of both the RRE and ROI techniques, and the similarity and proximity method for the RO1 technique. The method of selecting stations by list is not shown in the dialogue because it is a specialized method and should be used only when the user does not get a satisfactory result from the RO1 technique (see discussion of output) and the user elects not to use the regional regression equation. The list method is used by selecting $G$ as the option for selecting stations, then entering the number of stations to use and the eight-digit station number for each station, one to a line.

The example site is Judicial Ditch 11 in Sibley County, at the crossing of County Road 51, 3 miles south of Buffalo Lake. The relevant basin characteristics are:

Drainage area: $15.0 \mathrm{mi}^{2}$,

Main-channel slope: $2.6 \mathrm{ft} / \mathrm{mi}$,

Storage: 0.0 percent,

Lake area: 0.0 percent,

Generalized runoff: 4.0 in./yr,

Latitude: $44^{\circ} 41^{\prime} 22^{\prime \prime}$, and

Longitude: $94^{\circ} 37^{\prime} 10^{\prime \prime}$.

The example site is in region $\mathrm{D}$, where the recommended technique is $\mathrm{ROI}$ using the similarity method. RRE and ROI using the proximity method are also shown as an example.
Table 4.--PRESS/n statistics for each region and recurrence interval.

[ROI, region of influence regression]

\begin{tabular}{|c|c|c|c|c|}
\hline \multirow[b]{2}{*}{$\begin{array}{l}\text { Region } \\
\text { identifier }\end{array}$} & \multirow[b]{2}{*}{$\begin{array}{l}\text { Recurrence } \\
\text { interval } \\
\text { (years) }\end{array}$} & \multicolumn{3}{|c|}{ PRESS/n } \\
\hline & & $\begin{array}{l}\text { Proximity } \\
\text { method } \\
\text { ROI }\end{array}$ & $\begin{array}{l}\text { Similarity } \\
\text { method } \\
\text { ROI }\end{array}$ & $\begin{array}{l}\text { Regional } \\
\text { regression }\end{array}$ \\
\hline $\mathrm{A}$ & 2 & 0.0431 & 0.0425 & 0.0358 \\
\hline A & 5 & .0411 & .0369 & .0411 \\
\hline A & 10 & .0402 & .0350 & .0401 \\
\hline A & 25 & .0439 & .0392 & .0442 \\
\hline A & 50 & .0458 & .0436 & .0534 \\
\hline A & 100 & .0498 & .0493 & .0628 \\
\hline $\mathrm{A}($ mean $)$ & & .0440 & .0411 & .0462 \\
\hline B & 2 & .0362 & .0360 & .0337 \\
\hline B & 5 & .0413 & .0423 & .0430 \\
\hline B & 10 & .0447 & .0507 & .0445 \\
\hline B & 25 & .0488 & .0603 & .0510 \\
\hline B & 50 & .0516 & .0682 & .0546 \\
\hline B & 100 & .0543 & .0770 & .0598 \\
\hline B (mean) & & .0462 & .0558 & .0478 \\
\hline $\mathrm{C}$ & 2 & .0232 & .0344 & .0318 \\
\hline $\mathrm{C}$ & 5 & .0314 & .0404 & .0339 \\
\hline $\mathrm{C}$ & 10 & .0385 & .0429 & .0383 \\
\hline $\mathrm{C}$ & 25 & .0466 & .0561 & .0445 \\
\hline $\mathrm{C}$ & 50 & .0532 & .0630 & .0496 \\
\hline $\mathrm{C}$ & 100 & .0599 & .0685 & .0549 \\
\hline $\mathrm{C}$ (mean) & & .0421 & .0509 & .0422 \\
\hline $\mathrm{D}$ & 2 & .0453 & .0449 & .0498 \\
\hline $\mathrm{D}$ & 5 & .0442 & .0421 & .0435 \\
\hline $\mathrm{D}$ & 10 & .0528 & .0466 & .0473 \\
\hline $\mathrm{D}$ & 25 & .0705 & .0560 & .0566 \\
\hline $\mathrm{D}$ & 50 & .0828 & .0649 & .0654 \\
\hline $\mathrm{D}$ & 100 & .0957 & .0747 & .0752 \\
\hline $\mathrm{D}$ (mean) & & .0652 & .0549 & .0563 \\
\hline $\mathrm{E}$ & 2 & .0856 & .0594 & .0809 \\
\hline $\mathrm{E}$ & 5 & .0734 & .0538 & .0578 \\
\hline $\mathrm{E}$ & 10 & .0778 & .0591 & .0550 \\
\hline $\mathrm{E}$ & 25 & .0903 & .0729 & .0582 \\
\hline E & 50 & .1074 & .0838 & .0638 \\
\hline $\mathrm{E}$ & 100 & .1204 & .1004 & .0713 \\
\hline $\mathrm{E}$ (mean) & & .0925 & .0716 & .0645 \\
\hline $\mathrm{F}$ & 2 & .0423 & .0485 & .0348 \\
\hline $\mathrm{F}$ & 5 & .0315 & .0428 & .0301 \\
\hline $\mathrm{F}$ & 10 & .0297 & .0457 & .0312 \\
\hline $\mathrm{F}$ & 25 & .0332 & .0527 & .0350 \\
\hline $\mathrm{F}$ & 50 & .0384 & .0545 & .0392 \\
\hline $\mathrm{F}$ & 100 & .0432 & .0605 & .0443 \\
\hline $\mathrm{F}$ & mean & .0364 & .0508 & .0358 \\
\hline
\end{tabular}


The dialogue lists the peak flow, standard error of prediction (SEP) (discussed in the Accuracy and Limitations of Estimating Techniques section), equivalent years of record, and the lower and upper flow values of the 90-percent prediction interval. The SEP for the RRE will always be equal to or larger than the value of the SEE in table 3 .

The output file from the regional regression equation technique reiterates the screen output and is not shown in this report. The output from the region of influence regression technique contains additional diagnostics about the regressions. A section of the output file is shown in the Supplemental Information section. The basic form of the output is repeated for each recurrence interval.

The output file presents information about the regression analysis. First, the results of the stepbackward selection of independent variables are shown. Second, the residuals and influence statistics are listed. Third, the estimated peak flow and statistics are shown.

The output from the step-backward selection process shows the coefficients and their statistics, the variable to be deleted, and the reason for deletion for each of the steps. If the variable is forced out of the analysis, the coefficients and statistics are not shown.

The residuals and influence list includes the stations used in the analysis, the base-10 logarithm of the observed peak, the base-10 logarithm of the predicted peak, the studentized residual, the leverage, and Cook's D for each station. The studentized residual is the computed residual divided by the estimated standard deviation of that residual. Leverage is a measure of the distance from the observation to the mean of all observations. The leverage statistic can identify stations that are potentially influential because of their location in independent-variable space. Cook's D is a measure of influence that uses the studentized residual and leverage. Cook's D reveals which observations are influential in affecting the coefficients of the regression equation. Stations with values of the studentized residual, leverage, and Cook's D that are substantially larger than any other of the respective values could be considered for deletion. If basin characteristics of a particular station are substantially different from the remaining stations and the site in question, it could be deleted from the analysis and the remaining stations used in the ROI technique, using the list method.

Two statistics are printed at the bottom of the list. They are the mean sampling error variance and the mean model error variance. The mean sampling error variance is the portion of the average prediction error that is caused by estimation errors in the regression coefficients as opposed to the model error. The mean model error variance is the error caused by an imperfect model (lack of fit). The sum of these numbers is the mean prediction error variance. Hodge and Tasker (1995) describe the development of these statistics.

The predicted peak flow and statistics reiterate the information shown on the screen. The statistics include the percent standard error of prediction, the equivalent years of record, and the upper and lower 90-percent prediction interval. These statistics are explained in the Accuracy and Limitations of the Estimating Techniques section. The output on the screen will include a caution statement if the predicted value for a peak is smaller than the predicted value for a shorter recurrence interval.

The program will make a second pass through all regressions to construct a set of equations for estimating peak-flow that are based on a consistent set of independent variables. Independent variables that are used in at least three of the peak-flow estimates are included in that consistent set. Predicted peak flows based on a consistent set of independent variables may be desirable in all cases and should eliminate the occurrence of smaller predicted values at longer recurrence intervals.

\section{ACCURACY AND LIMITATIONS OF THE ESTIMATING TECHNIQUES}

The accuracy of a statistically derived equation is measured by the closeness of the estimated value to the true value. Regression analyses give an unbiased estimate of the true value and statistics to assess the accuracy of the estimate.

The standard error of the estimate (SEE) is a measure of the fit of the observed data about the regression surface. The SEE is expressed as a percentage of the estimated value. It has traditionally been used for comparing the relative accuracy of the equations, although it is less useful for GLS regressions.

The standard error of prediction (SEP) is an estimate of the accuracy of the result of applying a 
regression equation to a set of independent variables. It accounts for the regression error and the uncertainty of the coefficients of the independent variables. It varies from site to site because it is a function of the basin characteristics at a site.

Hardison (1971) presented an equation that defines the equivalent years of record (EY) represented by the regression equation. The $\mathrm{EY}$ is the ratio of the mean variance of the logarithms of the annual peak to the mean square error of prediction, multiplied by a factor dependent on the recurrence interval. It is an estimate of the number of years of record that would be needed at a site to compute a peak flow at that recurrence interval with the same confidence interval.

The 90 percent confidence interval is another measure of the uncertainty of the predicted value. It is the estimated value multiplied or divided by a factor that is dependent on the mean SEP and the critical value of the $t$-distribution for a particular model. The information necessary to compute prediction intervals are in the file predict.dat on the disk included with this report.

The accuracy of the estimating equation is limited by the variance and bias of the input data. Variance is a measure of the random variation about the true value, and bias is the consistent deviation of the value from the true value.

The accuracy of the regression estimate is affected by errors in the independent variables. Errors in quantifying the drainage-basin characteristics result from an inability to completely describe the effect of those characteristics. For example, the effects of wetlands and lakes depend on their size and location in the basin and in the stream channels, but the independent variable storage is simply expressed as a percentage of total drainage area without regard to size or location.

Bias of an estimate can result from systematic errors in the computation of the dependent variable. Bias in the computation of the dependent variable is probably the result of collecting peakflow data over a period of time that does not reflect the long-term population of peak flows. Most short-term records at streamflow gaging stations used in this analysis were from the 1960-85 and current (through 1995) periods. The derived peakflow statistics reflect those periods, which may not be representative of the long-term conditions.
The accuracy of an estimate made using the techniques presented in this report can also be affected by the user. Each user will make certain decisions based on his or her best judgement about the actual outline of the drainage basin, the path of the main channel, interpolation of generalized runoff, and the source of lake and wetland data. These individual sources of error can be reduced by use of shared computer data sets that are updated as improved information becomes available and the use of geographic information systems that provide consistent results.

The accuracy of peak-flow estimates made at sites immediately downstream of a lake or ponding area where the storage capacity could substantially alter peak-flow characteristics can be improved by a routing adjustment. In such places, the frequency relations could be used as an aid in developing a hydrograph of the inflow and then a simulation of that flow can be routed through the lake to determine the peak of the outflow.

The values of the independent variables used in this analysis were all computed from consistent data sets using a GIS or spatial interpolation software. It is expected that careful analysis using 7 1/2-minute USGS topographic maps should provide accurate estimates of drainage area, mainchannel slope, percent storage, and percent lake. Interpolation of generalized runoff from figure 2 can be improved by using runoff data from table 2 in conjunction with data for nearby streamflow gaging stations.

Multi-collinearity among the independent variables can have adverse effects on the accuracy of coefficients of those variables in the regression equation (Helsel and Hirsch, 1992). Freund and Minton (1979) indicated that predictions from regressions where the independent variables exhibit multi-collinearity are reliable where the correlation structure of the predicted site is similar to that of the data used to construct the regression equation. This condition likely is true for any site in Minnesota using any of the techniques for predicting peak flow described herein.

Collinearity can be intrinsic in the data, such as the relation between main-channel slope and drainage area, or introduced in the computation of variables, such as percent storage and percent lake. The correlation (a measure of collinearity) between slope and drainage area is about -.85 for regions in Minnesota. The correlation between percent storage and percent lake is less than 0.6 for regions in Minnesota. A measure of multi-collinearity is 
the variance inflation factor (VIF). Helsel and Hirsch (1992) stated that VIFs of less than 10 were not a concern in multiple linear regression analyses. The VIF for each independent variable in each regional regression equation in this study was less than 8 .

Peak-flow-frequency equations presented in this report can be used to estimate the peak flows of several recurrence intervals on most small streams in Minnesota. The applicability and accuracy of these relations depend partly on whether the basin characteristics of the site are within the range of the characteristics used to define the peak-flow equations. The range in sampled basin characteristics is large enough to allow the application of the equations at most sites where streamflow is not affected by regulation, diversion, or urbanization. The upper and lower value and geometric mean for each basin characteristic for each region are listed in table 5 .

Table 5.--Upper and lower values and geometric mean of the independent variables used in the regional regression analysis for each region. $\left[\mathrm{mi}^{2}\right.$, square miles; $\mathrm{ft} / \mathrm{mi}$, feet per mile]

\begin{tabular}{|c|c|c|c|c|}
\hline & $\begin{array}{c}\text { Drainage } \\
\text { area } \\
\left(\mathrm{mi}^{2}\right)\end{array}$ & $\begin{array}{l}\text { Main- } \\
\text { channel } \\
\text { slope } \\
\text { (ft/mi) }\end{array}$ & $\begin{array}{l}\text { Storage } \\
\text { (percent) }\end{array}$ & $\begin{array}{c}\text { Lake } \\
\text { (percent) }\end{array}$ \\
\hline \multicolumn{5}{|c|}{ REGION A } \\
\hline Upper & 1560 & 36.7 & 72 & 10 \\
\hline Mean & 82 & 6.2 & 17 & .7 \\
\hline Lower & 1.2 & 1.3 & 0.1 & .0 \\
\hline \multicolumn{5}{|c|}{ REGION B } \\
\hline Upper & 1680 & 251 & 95 & 26 \\
\hline Mean & 66 & 5.9 & 26 & 2.2 \\
\hline Lower & .4 & .4 & 1.7 & .0 \\
\hline \multicolumn{5}{|c|}{ REGION C } \\
\hline Upper & 609 & 214 & 46 & 21 \\
\hline Mean & 19 & 33 & 18 & 1.4 \\
\hline Lower & .5 & 4.5 & 0.8 & .0 \\
\hline \multicolumn{5}{|c|}{ REGION D } \\
\hline Upper & 2640 & 219 & 44 & 23 \\
\hline Mean & 26 & 9.6 & 4.8 & .9 \\
\hline Lower & .1 & .9 & .0 & .0 \\
\hline \multicolumn{5}{|c|}{ REGION E } \\
\hline Upper & 790 & 122 & 5.7 & 2.4 \\
\hline Mean & 14 & 16 & .8 & .1 \\
\hline Lower & .2 & 4.0 & .0 & .0 \\
\hline \multicolumn{5}{|c|}{ REGION F } \\
\hline Upper & 1540 & 237 & 4.1 & .7 \\
\hline Mean & 25 & 20 & 1.1 & .1 \\
\hline Lower & .1 & 3.1 & .0 & .0 \\
\hline
\end{tabular}

The geometric mean is included because it best represents the mean of the data. Where runoff is included as an independent variable, the range of those data is sufficient to ensure that any value in that region is within the range. The program will issue a warning message if the predicted peak flow is an extrapolation beyond the data on which the prediction is based

\section{SUMMARY}

This report (1) documents the analytical techniques used for annual series peak-flowfrequency computations, basin characterization, regionalization, and development of equations for estimating peak flows on small drainage basins; (2) presents peak-flow data and basin characteristics at streamflow gaging stations; and (3) discusses techniques for estimating peak flow at ungaged sites on small, unregulated streams in Minnesota.

Two statistically derived techniques, regional regression equation and region of influence regression, for estimating peak flow on small, ungaged streams in Minnesota were developed. Both of the techniques relate physical and climatic characteristics to peak flows for 2-, 5-, 10-, 25-, $50-$, and 100-year recurrence intervals. Regional regression equations were developed for each recurrence interval in each of the six regions in Minnesota. The region of influence regression technique dynamically selects stations with characteristics similar to site of interest. Two methods of selecting streamflow gaging stations, similarity and proximity, can be used in the region of influence regression technique. Thus, the region of influence regression technique allows use of a potentially unique set of stations for estimating peak flow at each site of interest.

The regional regression equation technique is preferable as a first estimate of peak flow in regions $\mathrm{C}, \mathrm{E}$, and $\mathrm{F}$. The similarity method of the region of influence regression technique is preferable as a first estimate in regions $\mathrm{A}$ and $\mathrm{D}$. The proximity method should be used as a first estimate in region $B$.

Tables showing the peak-flow-frequency data and basin characteristics for streamflow gaging stations, and regional peak-flow prediction equations are documented in the report and in the Supplemental Information section. 


\section{SELECTED REFERENCES}

Akima, H., 1978, Bivariate interpolation and smooth surface fitting for irregularly distributed data points: Association for Computing Machinery, Transactions on Mathematical Software, v. 4, no. 2, p. 160-164.

Burn, D.H., 1990, Evaluation of regional flood frequency analysis with a region of influence approach: Water Resources Research, v. 26, no. 10 , p. $149-165$.

Freund, R.J. and Minton, P.D., 1979, Regression methods, a tool for data analysis: Marcel Dekker, Inc. New York, $261 \mathrm{p}$.

Gebert, W.A., Graczyk, K.J., and Krug, W.R., 1985, Average annual runoff in the United States, 195180: U.S. Geological Survey Open-File Report 85627,1 sheet, scale 1:2,000,000.

Guetzkow, L.C., 1977, Techniques for estimating magnitude and frequency of floods in Minnesota: U.S. Geological Survey Water-Resources Investigations 77-31, $33 \mathrm{p}$.

Hardison, C.H., 1971, Predicion of error of regressioin estimates of streamflow characteristics at gaged sites: U.S. Geolgical Survey Professional Paper 750-C, p. C228-C236.

Helsel, D.R. and Hirsch, R.M., 1992, Statistical methods in water resources: Elsevier, Amsterdam, The Netherlands, $522 \mathrm{p}$.

Hodge, S.A. and Tasker, G.D., 1995, Magnitude and frequency of floods in Arkansas: U.S. Geological Survey Water-Resources Investigations Report 954224, $275 \mathrm{p}$.

Jacques, J.E. and Lorenz, D.L., 1987, Techniques for estimating the magnitude and frequency of floods in Minnesota: U.S. Geological Survey WaterResources Investigations Report 87-4170, 48 p.

Lorenz, D.L., 1997, Generalized skew coefficients for flood-frequency analysis in Minnesota: U.S. Geological Survey Open-File Report 97-4089, $15 \mathrm{p}$.

Lorenz, D.L., and Payne, G.A., 1989, Selected data describing stream subbasins in the Redwood River Basin, southwestern Minnesota: U.S. Geological
Survey Open-File Report 89-405, 5 p., 1 plate, scale $1: 100,000$.

1991 a, Selected data for stream subbasins in the Le Sueur River Basin, south-central Minnesota: U.S. Geological Survey Open-File Report 91-62, 8 p., 1 plate, scale 1:100,000.

1991b, Selected data for stream subbasins in the Watonwan River Basin, south-central Minnesota: U.S. Geological Survey Open-File Report 91-61, 7 p., 1 plate, scale 1:100,000.

1992, Physical characteristics of stream subbasins in the Blue Earth River Basin, south-central Minnesota and north-central Iowa: U.S. Geological Survey Open-File Report 91-512, 10 p., 1 plate, scale $1: 100,000$.

1994, Physical characteristics of stream subbasins in the Pomme de Terre River Basin, west-central Minnesota: U.S. Geological Survey Open-File Report 93-47, 8 p., 1 plate, scale 1:100,000.

Lorenz, D.L., Sanocki, C.A., and Winterstein, T.A., 1994, Physical characteristics of stream subbasins in the Lac qui Parle River Basin, southwestern Minnesota and eastern South Dakota: U.S. Geological Survey Open-File Report 93-46, 12 p., 1 plate, scale $1: 100,000$.

Minnesota Department of Transportation, 1997, Basemap 97: Office of Land Management, Surveying and Mapping Section, 1 compact disk.

Patterson, J.L., and Gambel, G.R., 1968, Magnitude and frequency of floods in the United States, Part 5: U.S. Geological Survey Water-Supply Paper 1678, $546 \mathrm{p}$.

Prior, C.H., 1949, Magnitude and frequency of floods in Minnesota: Minnesota Department of Conservation, Division of Waters Bulletin 1, $128 \mathrm{p}$.

Prior, C.H. and Hess, J.H., 1961, Floods in Minnesota-Magnitude and frequency: Minnesota Department of Conservation, Division of Waters Bulletin 12, $142 \mathrm{p}$.

Sanocki, C.A., 1995a, Physical characteristics of stream subbasins in the Cottonwood River Basin, southwestern Minnesota: U.S. Geological Survey 
Open-File Report 95-333, 14 p., 1 plate, scale $1: 100,000$.

Sanocki, C.A., 1995b, Physical characteristics of stream subbasins in the Upper Minnesota River Basin, west-central Minnesota, northeastern South Dakota, and southeastern North Dakota: U.S. Geological Survey Open-File Report 95-162, 16 p., 1 plate, scale 1:100,000.

Sanocki, C.A., 1996a, Physical characteristics of stream subbasins in the Middle Minnesota-Little Cottonwood River Basin, south-central Minnesota: U.S. Geological Survey Open-File Report 96-631, 13 p., 1 plate, scale 1:100,000.

Sanocki, C.A., 1996b, Physical characteristics of stream subbasins in the Hawk Creek-Yellow Medicine River Basin, southwestern Minnesota and Eastern South Dakota: U.S. Geological Survey Open-File Report 96-632, 21 p., 1 plate, scale 1:100,000.

Sanocki, C.A., 1997a, Physical characteristics of stream subbasins in the Lower Minnesota River Basin, south-central Minnesota: U.S. Geological Survey Open-File Report 97-205, 16 p., 1 plate, scale $1: 100,000$.

Sanocki, C.A., in press, Physical characteristics of stream subbasins in the North Fork Crow River Basin, south-central Minnesota: U.S. Geological Survey Open-File Report.

Sanocki, C.A., in press, Physical characteristics of stream subbasins in the South Fork Crow River Basin, south-central Minnesota: U.S. Geological Survey Open-File Report.

Sanocki, C.A., and Krumrie, J.R., 1994, Physical characteristics of stream subbasins in the Chippewa River Basin, west-central Minnesota: U.S. Geological Survey Open-File Report 94-488, 16 p., 1 plate, scale 1:100,000.

Stedinger, J.D., and Tasker, G.D., 1985, Regional hydrologic analysis 1--Ordinary, weighted, and generalized least squares compared: Water Resources Research, v. 21, no. 9, p. 1421-1432.

Tasker, G.D., Eychaner, J.H., and Stedinger, J.R., 1986, Application of generalized least squares in hydrologic regression analysis, in Selected Papers in the Hydrologic Sciences: U.S. Geological Survey Water-Supply Paper 2310, p. 107-115.

Tasker, G.D., and Stedinger, J.D., 1989, An operational GLS model for hydrologic regression: Journal of Hydrology, v. 111, no. xx, p 361-375.

U.S. Water Resources Council, 1982, Guidelines for determining flood flow frequency, revised September 1981, Editorial corrections March 1982: Hydrology Committee Bulletin 17B, Washington, D.C., 190 p., 1 plate.

Wiitala, S.W., 1965, Magnitude and frequency of floods in the United States, Part 4: U.S. Geological Survey Water-Supply Paper 1677, 357 p. 
Supplemental Information 
18 


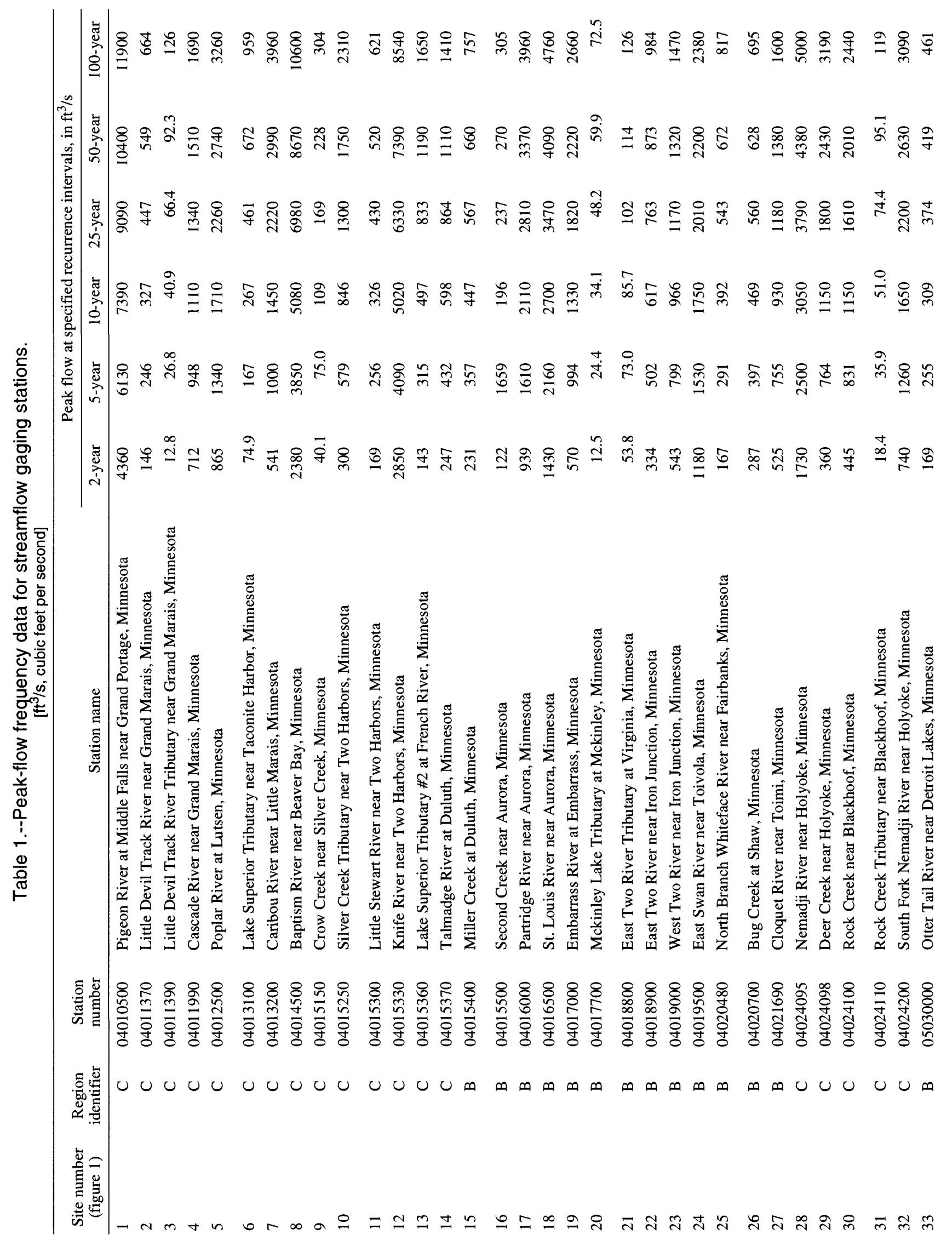




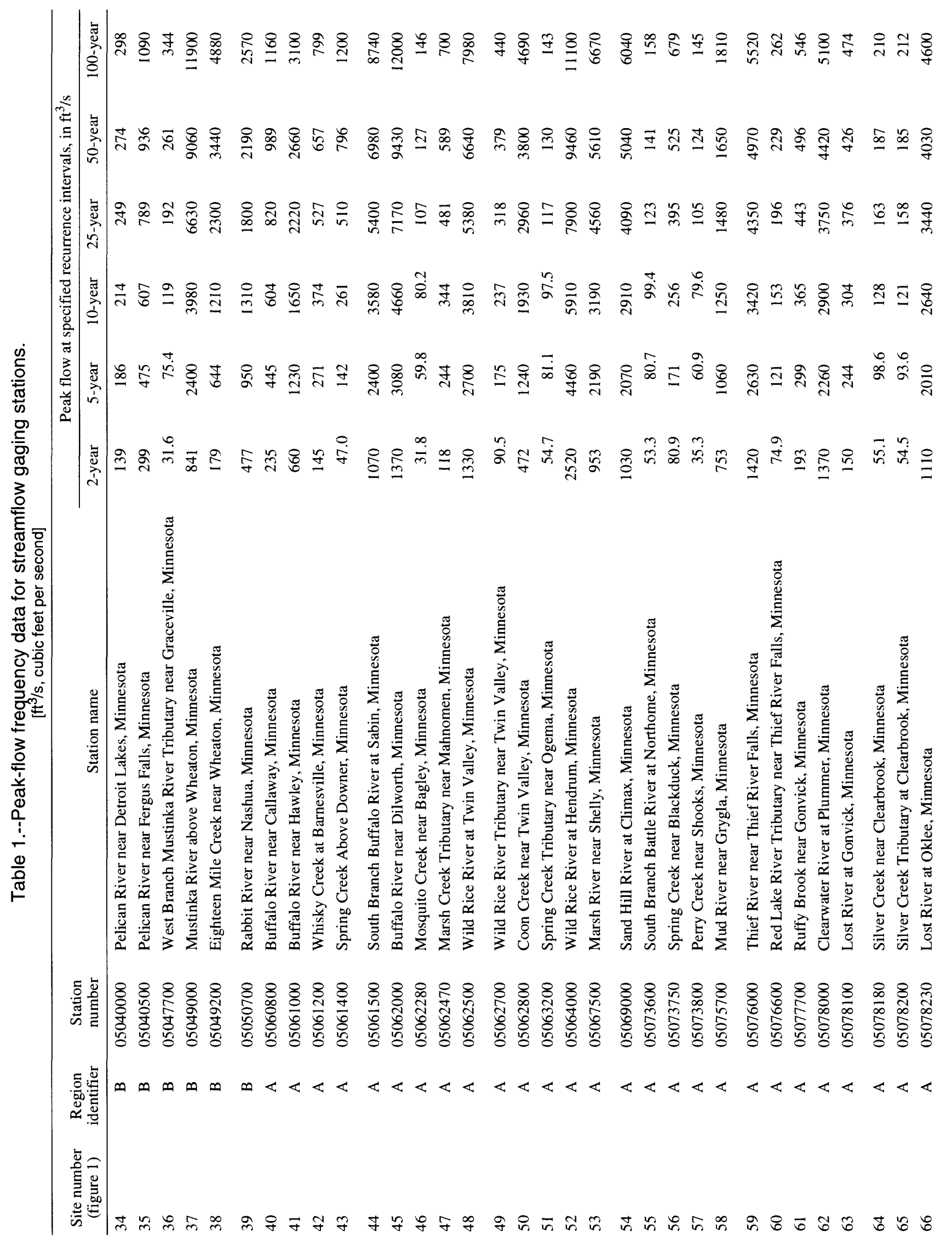




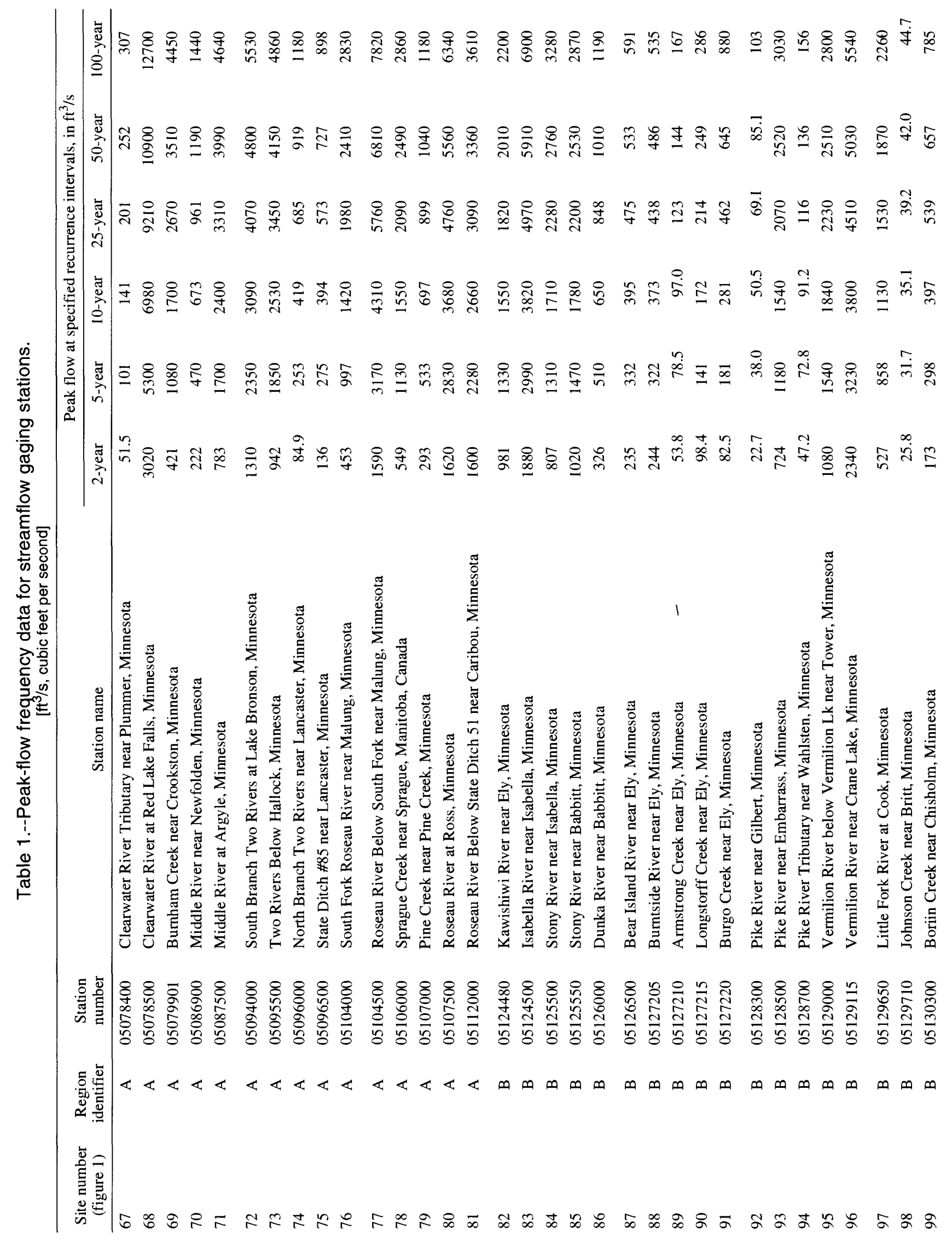




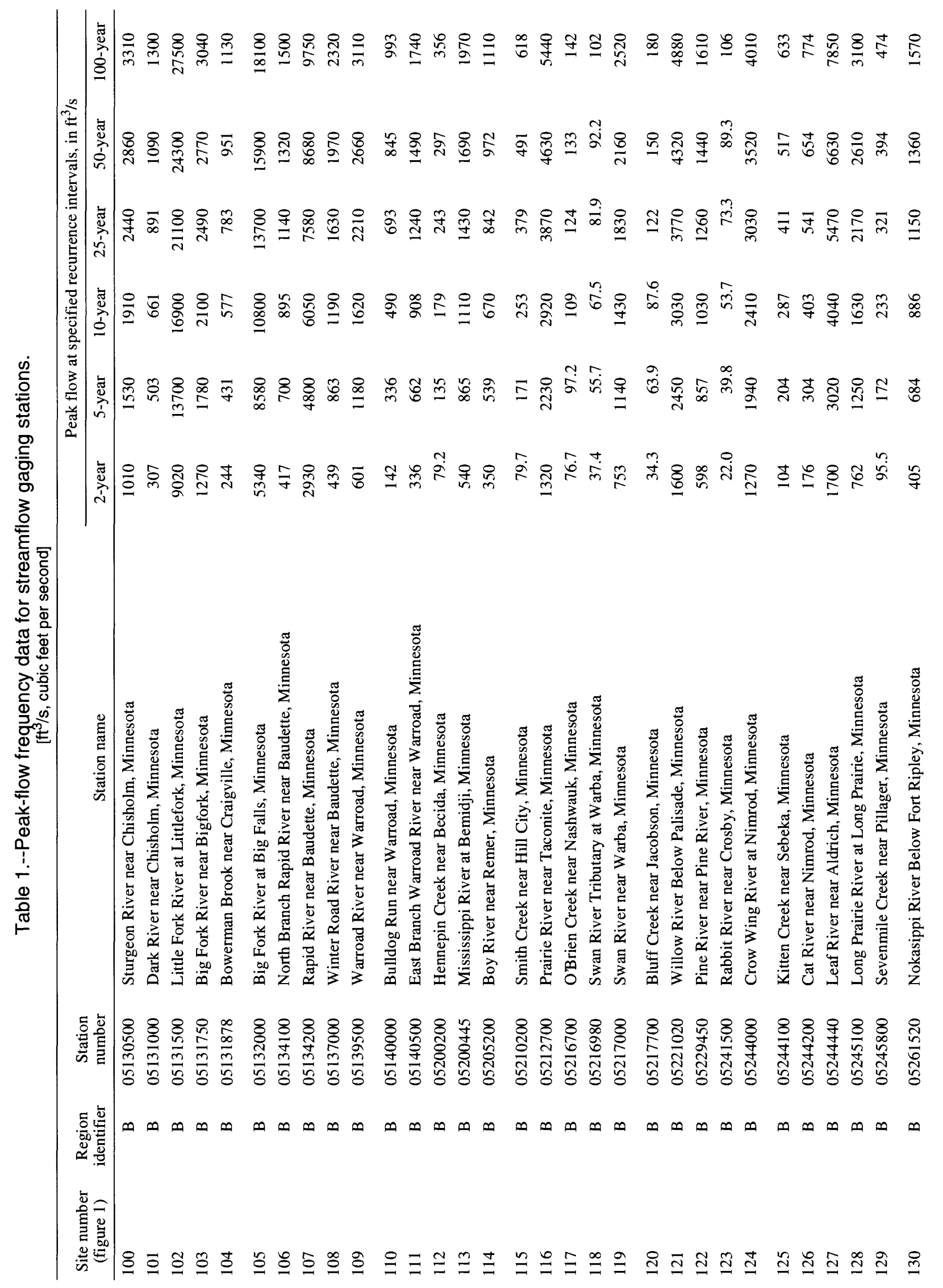




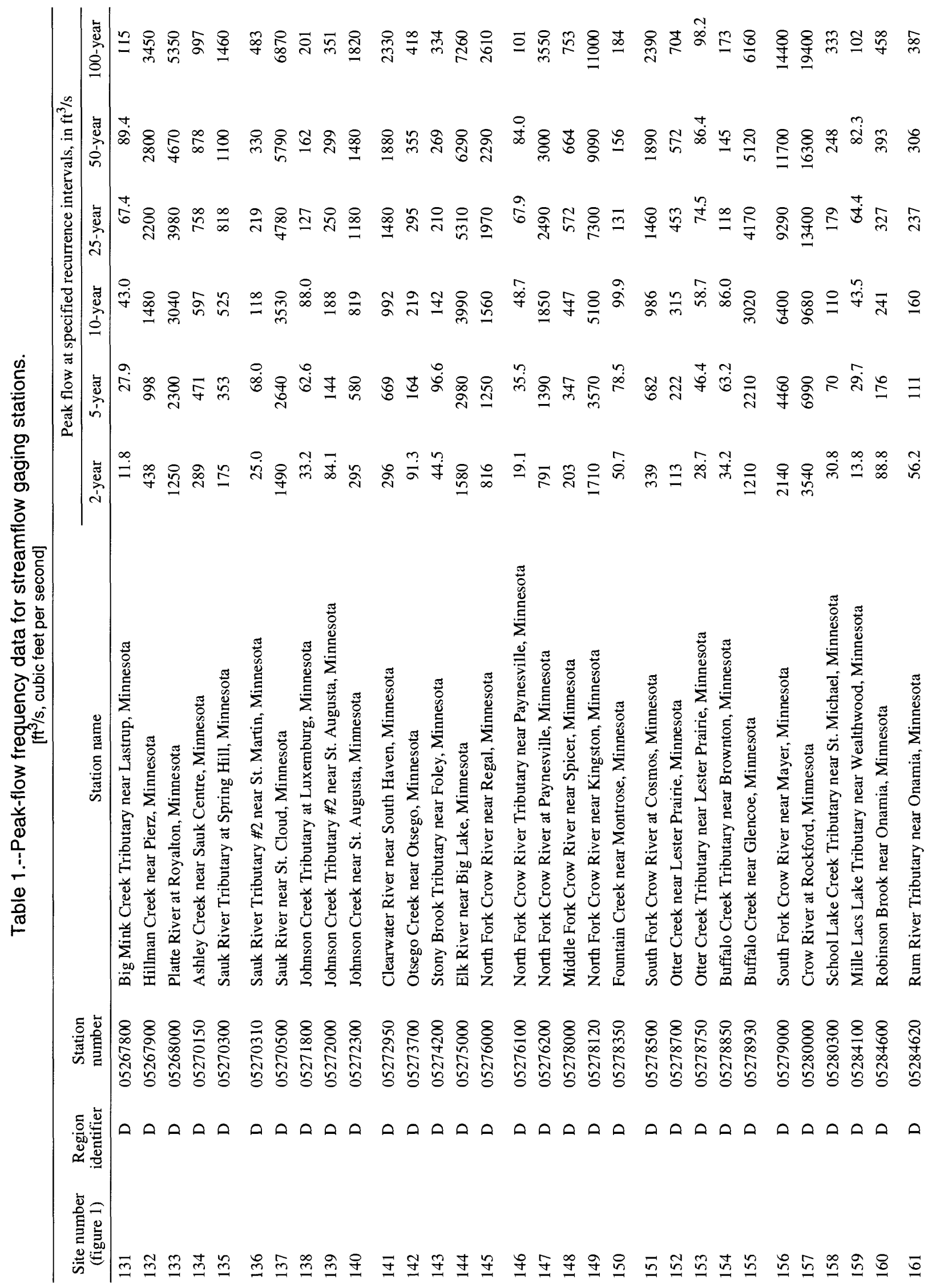




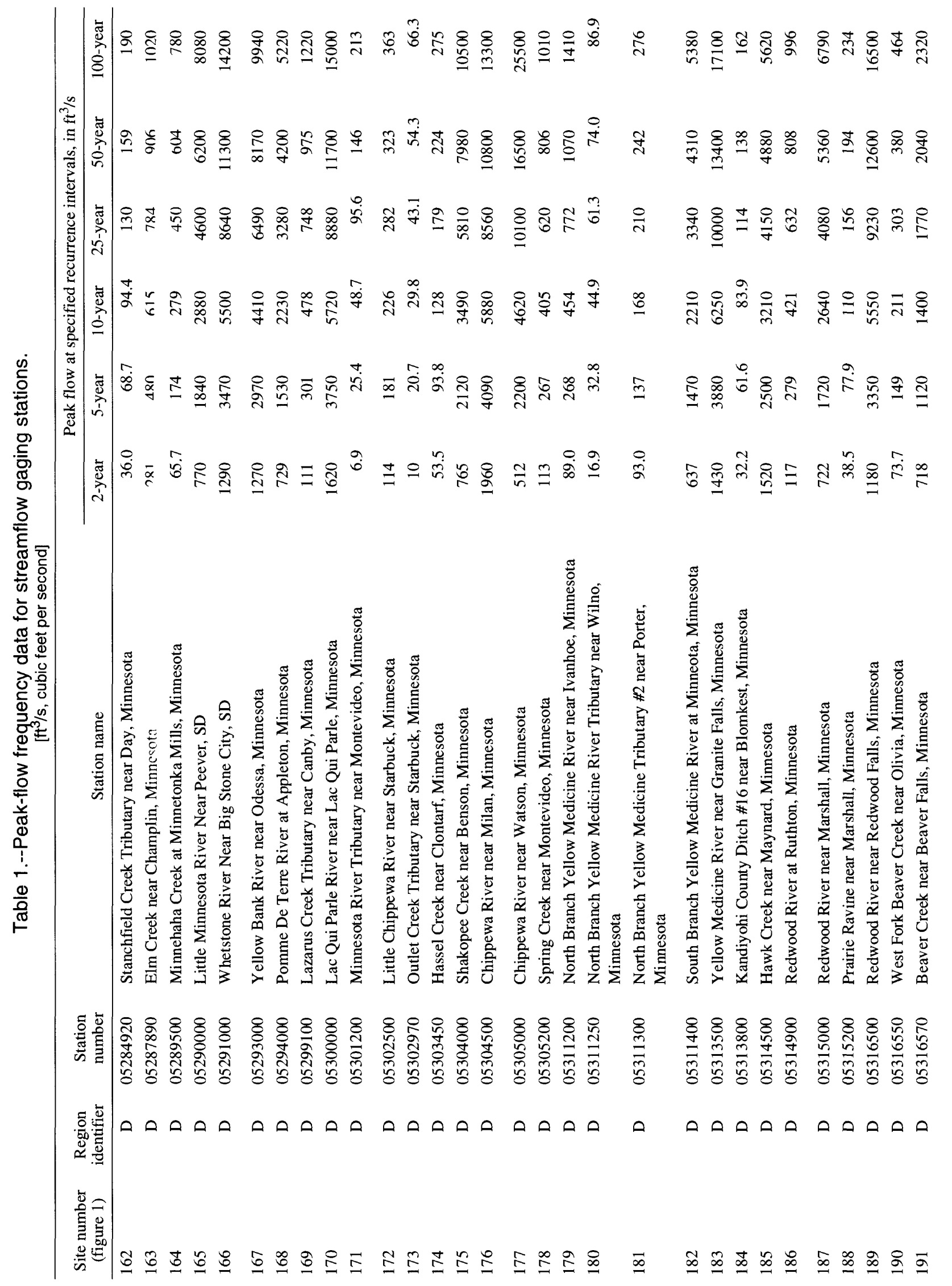




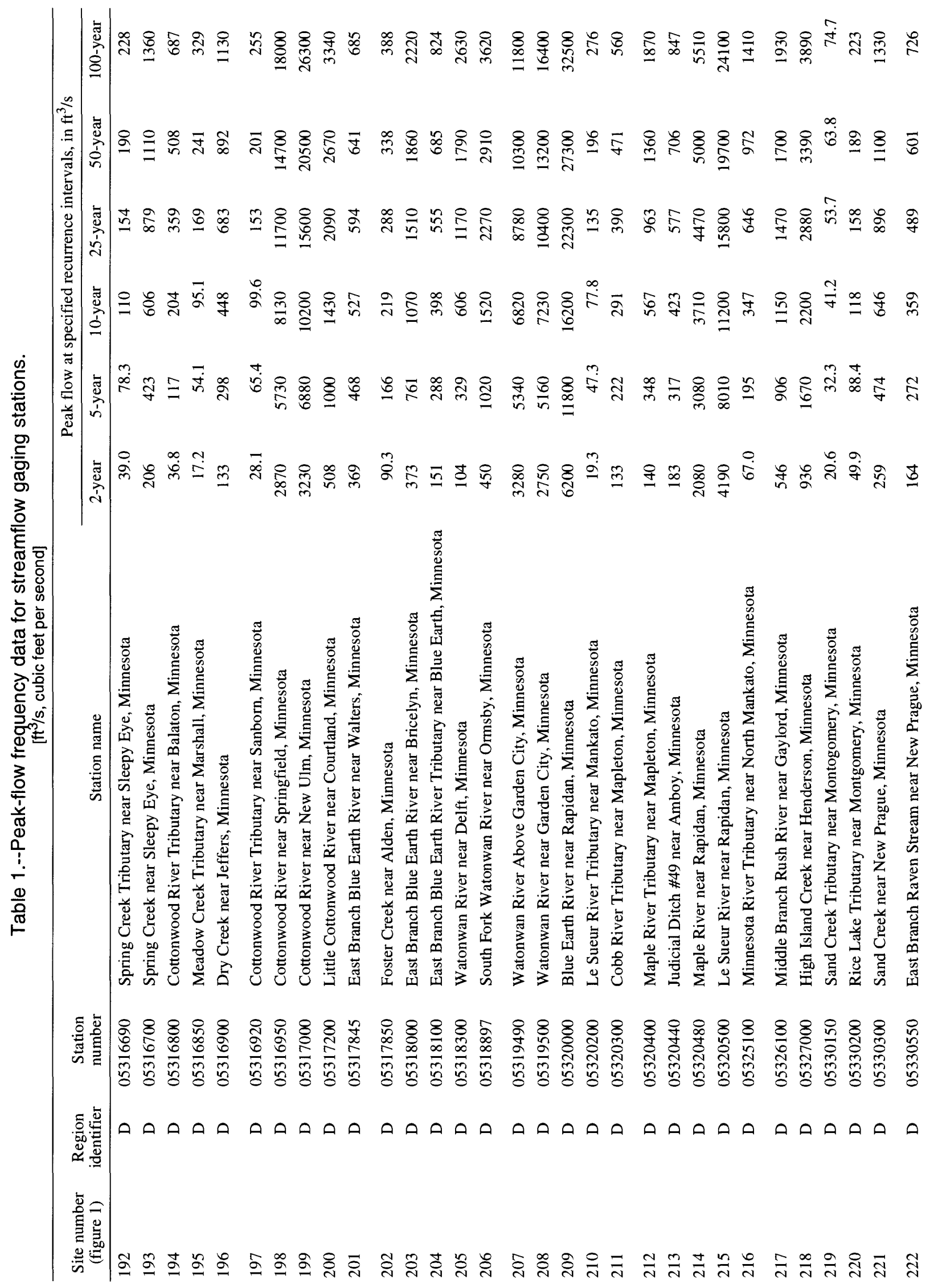




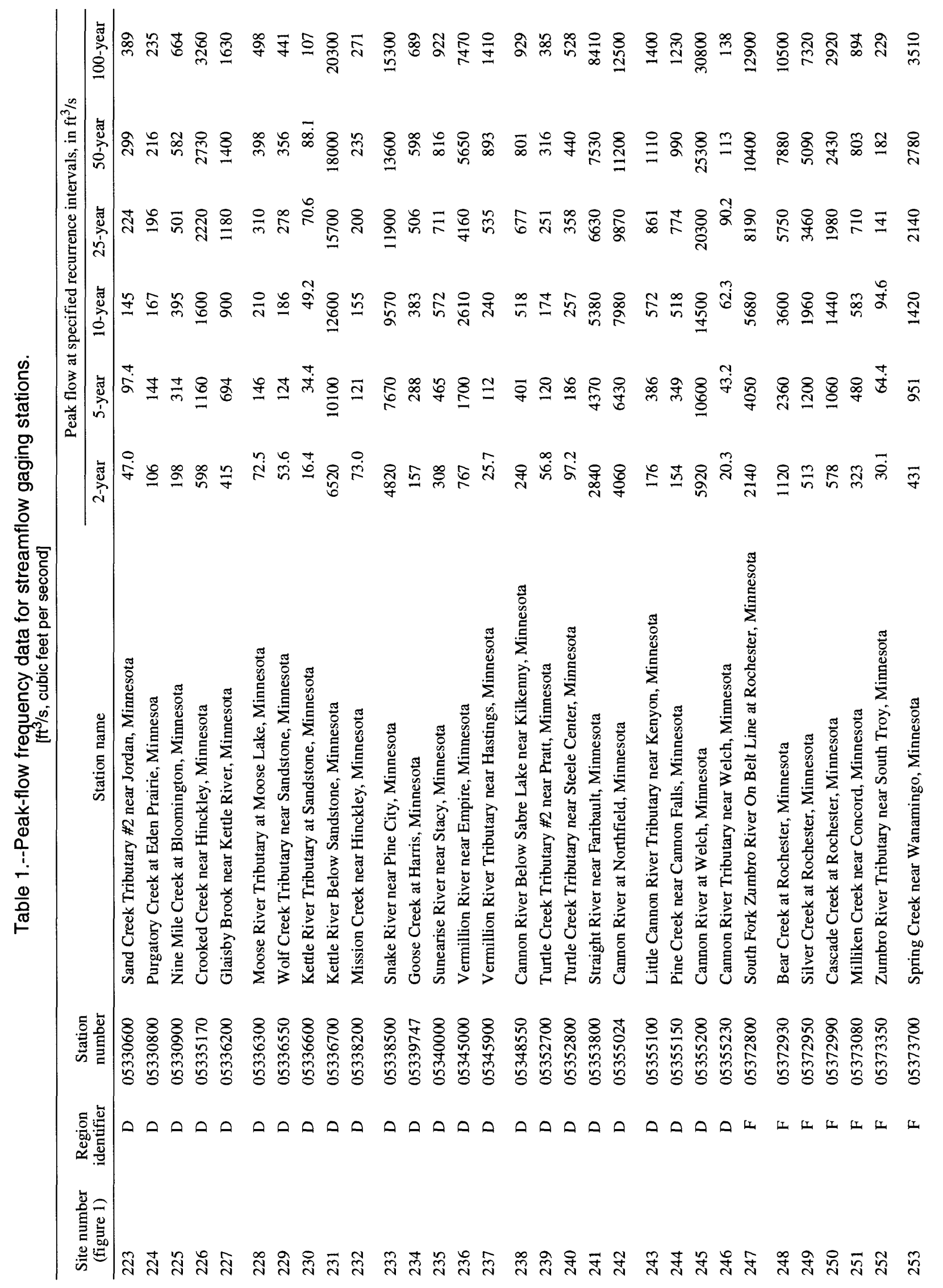




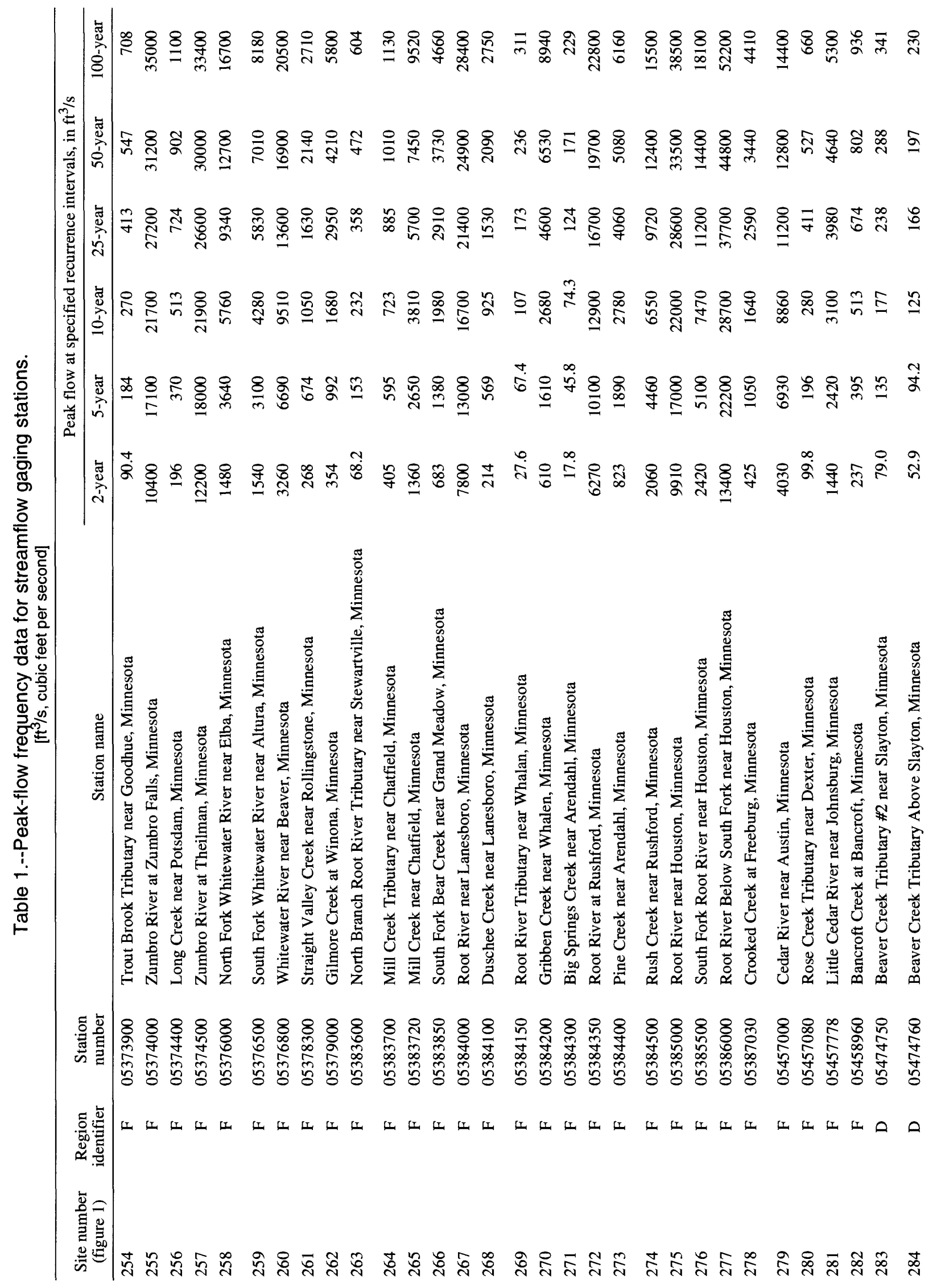




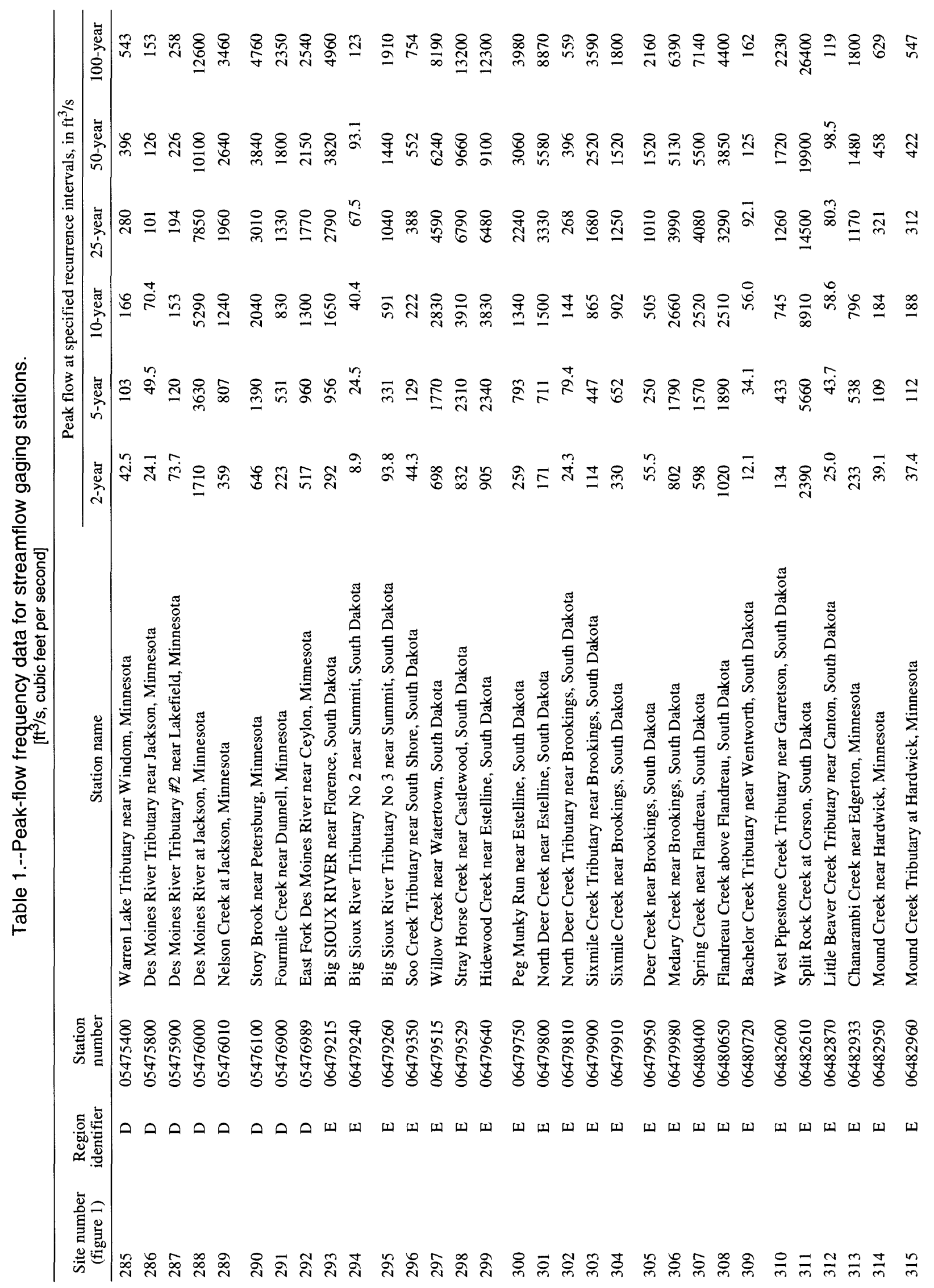




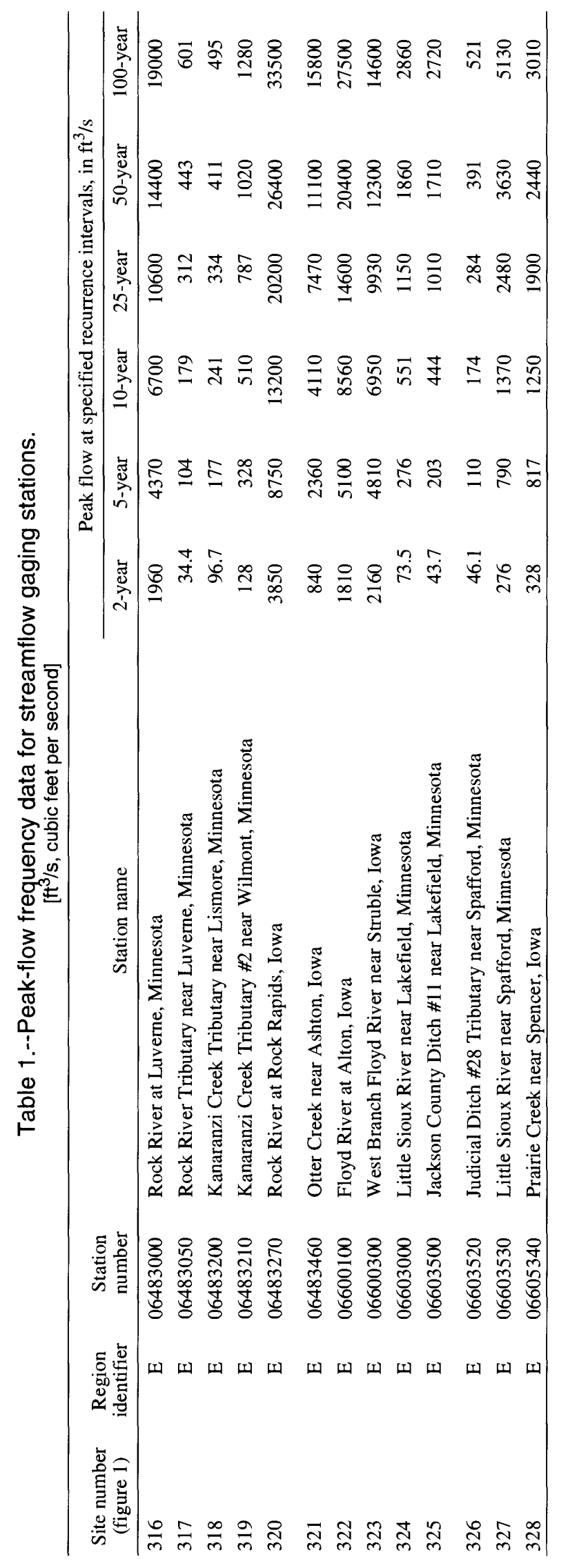


Table 2.--Basin characteristics for streamflow gaging stations.

$\left[\mathrm{mi}^{2}\right.$, square miles; $\mathrm{ft} / \mathrm{mi}$, feet per mile; in., inches; in./yr, inches per year]

\begin{tabular}{|c|c|c|c|c|c|}
\hline $\begin{array}{l}\text { Site number } \\
\text { (figure } 1)\end{array}$ & $\begin{array}{l}\text { Drainage } \\
\text { area }\end{array}$ & $\begin{array}{l}\text { Main-channel } \\
\text { slope }\end{array}$ & $\begin{array}{c}\text { Storage } \\
\text { (percentage of } \\
\text { drainage area) }\end{array}$ & $\begin{array}{c}\text { Lake } \\
\text { (percentage of } \\
\text { drainage area) }\end{array}$ & $\begin{array}{l}\text { Mean annual runoff } \\
\text { (in./yr) }\end{array}$ \\
\hline 1 & 609 & 11.2 & 19.3 & 11.6 & 11.7 \\
\hline 2 & 6.97 & 55.2 & 21.8 & 3.0 & 12.2 \\
\hline 3 & 0.47 & 127 & 17.0 & .0 & 12.2 \\
\hline 4 & 87.6 & 26.5 & 27.2 & 5.5 & 12.2 \\
\hline 5 & 114 & 20.9 & 27.4 & 7.3 & 12.7 \\
\hline 6 & 1.58 & 214 & 16.6 & .0 & 13.2 \\
\hline 7 & 22.6 & 56.4 & 15.1 & .0 & 13.4 \\
\hline 8 & 137 & 44.7 & 29.4 & 0.7 & 13.9 \\
\hline 9 & 1.04 & 111 & 25.8 & 0.0 & 14.2 \\
\hline 10 & 3.62 & 145 & 0.8 & 0.0 & 14.6 \\
\hline 11 & 4.96 & 56.2 & 13.0 & 0.0 & 14.6 \\
\hline 12 & 83.6 & 39.1 & 17.6 & 0.0 & 14.2 \\
\hline 13 & 1.44 & 144 & 3.1 & 0.0 & 14.4 \\
\hline 14 & 5.86 & 85.1 & 12.9 & 0.0 & 14.4 \\
\hline 15 & 4.91 & 25.9 & 18.3 & 0.0 & 12.5 \\
\hline 16 & 23.4 & 7.9 & 17.7 & 1.6 & 10.2 \\
\hline 17 & 159 & 7.8 & 33.4 & 2.7 & 10.2 \\
\hline 18 & 293 & 7.2 & 43.1 & 3.2 & 10.0 \\
\hline 19 & 95.4 & 3.6 & 37.7 & 2.8 & 10.1 \\
\hline 20 & 0.37 & 251 & 4.7 & 0.0 & 9.0 \\
\hline 21 & 4.46 & 23.7 & 8.9 & 1.2 & 8.6 \\
\hline 22 & 40.9 & 6.4 & 17.8 & 2.6 & 8.3 \\
\hline 23 & 67.3 & 8.7 & 18.7 & 3.4 & 8.3 \\
\hline 24 & 131 & 6.7 & 31.4 & 1.6 & 8.4 \\
\hline 25 & 17.1 & 7.3 & 47.9 & 0.3 & 12.2 \\
\hline 26 & 24.8 & 12.0 & 30.5 & 0.0 & 9.3 \\
\hline 27 & 40.8 & 16.7 & 54.8 & 1.1 & 13.2 \\
\hline 28 & 127 & 13.2 & 27.3 & 1.3 & 12.4 \\
\hline 29 & 7.7 & 45.5 & 15.9 & 0.0 & 12.4 \\
\hline 30 & 4.85 & 40.5 & 1.9 & 0.0 & 12.5 \\
\hline 31 & 0.49 & 36.9 & 14.2 & 0.0 & 12.5 \\
\hline 32 & 19.9 & 43.9 & 15.8 & 0.3 & 12.4 \\
\hline 33 & 218 & 4.6 & 33.9 & 15.2 & 3.4 \\
\hline 34 & 125 & 4.7 & 30.1 & 14.9 & 2.8 \\
\hline 35 & 486 & 2.2 & 27.4 & 15.2 & 1.9 \\
\hline 36 & 9.22 & 11.5 & 1.9 & 0.0 & 1.6 \\
\hline 37 & 810 & 2.1 & 6.9 & 1.5 & 1.6 \\
\hline 38 & 47.1 & 5.5 & 1.7 & 0.0 & 1.5 \\
\hline 39 & 99.2 & 4.8 & 5.6 & 1.6 & 1.5 \\
\hline 40 & 76.4 & 9.5 & 29.9 & 10.1 & 2.9 \\
\hline 41 & 325 & 6.2 & 17.0 & 4.9 & 1.7 \\
\hline 42 & 76.3 & 17.8 & 12.8 & 3.1 & 1.5 \\
\hline 43 & 7.93 & 14.7 & 5.5 & 0.0 & 1.4 \\
\hline 44 & 305 & 5.6 & 7.9 & 1.0 & 1.0 \\
\hline 45 & 975 & 2.6 & 10.9 & 2.3 & 1.0 \\
\hline
\end{tabular}


Table 2.--Basin characteristics for streamflow gaging stations.

$\left[\mathrm{mi}^{2}\right.$, square miles; $\mathrm{ft} / \mathrm{mi}$, feet per mile; in., inches; in./yr, inches per year]

\begin{tabular}{|c|c|c|c|c|c|}
\hline $\begin{array}{l}\text { Site number } \\
\text { (figure 1) }\end{array}$ & $\begin{array}{l}\text { Drainage } \\
\text { area }\end{array}$ & $\begin{array}{l}\text { Main-channel } \\
\text { slope }\end{array}$ & $\begin{array}{c}\text { Storage } \\
\text { (percentage of } \\
\text { drainage area) }\end{array}$ & $\begin{array}{c}\text { Lake } \\
\text { (percentage of } \\
\text { drainage area) }\end{array}$ & $\begin{array}{l}\text { Mean annual runoff } \\
\text { (in./yr) }\end{array}$ \\
\hline 46 & 4.0 & 11.2 & 5.6 & 0.0 & 4.2 \\
\hline 47 & 13.0 & 4.1 & 5.7 & 0.0 & 2.9 \\
\hline 48 & 934 & 4.2 & 18.8 & 4.2 & 2.3 \\
\hline 49 & 4.75 & 17.7 & 7.7 & 0.0 & 2.1 \\
\hline 50 & 50.1 & 12.7 & 7.4 & 0.0 & 2.1 \\
\hline 51 & 4.99 & 3.0 & 21.7 & 0.0 & 2.9 \\
\hline 52 & 1560 & 4.4 & 13.5 & 2.6 & 0.9 \\
\hline 53 & 220 & 7.3 & 4.3 & 0.1 & 1.2 \\
\hline 54 & 420 & 4.8 & 8.4 & 1.5 & 1.3 \\
\hline 55 & 2.8 & 8.8 & 28.8 & 2.2 & 5.7 \\
\hline 56 & 8.23 & 14.3 & 32.5 & 0.4 & 5.5 \\
\hline 57 & 1.16 & 10.3 & 72.2 & 0.0 & 5.6 \\
\hline 58 & 150 & 3.1 & 48.1 & 0.0 & 3.9 \\
\hline 59 & 985 & 1.9 & 55.2 & 1.3 & 3.2 \\
\hline 60 & 2.35 & 5.5 & 0.1 & 0.0 & 3.4 \\
\hline 61 & 46.2 & 11.1 & 18.3 & 2.3 & 4.6 \\
\hline 62 & 555 & 3.4 & 23.2 & 1.3 & 3.7 \\
\hline 63 & 51.3 & 6.0 & 21.5 & 5.4 & 4.6 \\
\hline 64 & 5.05 & 36.7 & 20.4 & 0.0 & 4.5 \\
\hline 65 & 6.18 & 34.2 & 16.2 & 1.1 & 4.6 \\
\hline 66 & 254 & 4.9 & 17.2 & 1.2 & 4.1 \\
\hline 67 & 6.61 & 13.2 & 5.2 & 0.0 & 3.5 \\
\hline 68 & 1380 & 5.3 & 18.9 & 2.0 & 3.1 \\
\hline 69 & 134 & 11.1 & 13.3 & 0.1 & 1.7 \\
\hline 70 & 88.8 & 9.3 & 14.6 & 0.0 & 2.9 \\
\hline 71 & 255 & 4.3 & 11.3 & 0.0 & 1.9 \\
\hline 72 & 422 & 4.0 & 13.4 & 0.2 & 2.4 \\
\hline 73 & 637 & 4.3 & 12.7 & 0.1 & 2.0 \\
\hline 74 & 38.3 & 3.9 & 17.9 & 0.0 & 2.4 \\
\hline 75 & 92.8 & 1.7 & 43.7 & 0.0 & 2.4 \\
\hline 76 & 219 & 3.3 & 36.8 & 0.0 & 3.4 \\
\hline 77 & 424 & 3.3 & 48.6 & 0.2 & 3.3 \\
\hline 78 & 176 & 5.1 & 15.8 & 0.0 & 3.2 \\
\hline 79 & 83.0 & 13.2 & 7.2 & 0.0 & 3.1 \\
\hline 80 & 1090 & 2.0 & 35.9 & 0.1 & 3.1 \\
\hline 81 & 1420 & 1.3 & 36.7 & 0.2 & 2.6 \\
\hline 82 & 254 & 7.3 & 27.0 & 11.4 & 11.3 \\
\hline 83 & 339 & 7.3 & 29.9 & 4.7 & 11.6 \\
\hline 84 & 214 & 7.8 & 46.4 & 3.5 & 11.8 \\
\hline 85 & 215 & 9.8 & 46.3 & 3.5 & 11.6 \\
\hline 86 & 55.1 & 13.0 & 36.7 & 0.3 & 11.3 \\
\hline 87 & 65.6 & 4.5 & 37.9 & 9.0 & 10.9 \\
\hline 88 & 68.9 & 13.3 & 31.9 & 21.4 & 10.5 \\
\hline 89 & 5.99 & 45.1 & 29.4 & 0.0 & 10.5 \\
\hline 90 & 8.6 & 28.2 & 30.3 & 9.0 & 10.6 \\
\hline
\end{tabular}


Table 2.--Basin characteristics for streamflow gaging stations.

$\left[\mathrm{mi}^{2}\right.$, square miles; $\mathrm{ft} / \mathrm{mi}$, feet per mile; in., inches; in./yr, inches per year]

\begin{tabular}{|c|c|c|c|c|c|}
\hline $\begin{array}{l}\text { Site number } \\
\text { (figure 1) }\end{array}$ & $\begin{array}{l}\text { Drainage } \\
\text { area }\end{array}$ & $\begin{array}{l}\text { Main-channel } \\
\text { slope }\end{array}$ & $\begin{array}{c}\text { Storage } \\
\text { (percentage of } \\
\text { drainage area) }\end{array}$ & $\begin{array}{c}\text { Lake } \\
\text { (percentage of } \\
\text { drainage area) }\end{array}$ & $\begin{array}{l}\text { Mean annual runoff } \\
\text { (in./yr) }\end{array}$ \\
\hline 91 & 2.84 & 48.4 & 18.1 & 1.1 & 10.7 \\
\hline 92 & 0.7 & 109 & 3.3 & 0.0 & 8.8 \\
\hline 93 & 118 & 4.2 & 35.2 & 1.8 & 9.7 \\
\hline 94 & 2.71 & 17.9 & 41.1 & 3.5 & 9.8 \\
\hline 95 & 490 & 1.8 & 39.2 & 17.4 & 9.5 \\
\hline 96 & 905 & 3.0 & 34.4 & 12.8 & 9.1 \\
\hline 97 & 68.2 & 3.3 & 56.0 & 1.7 & 9.1 \\
\hline 98 & 7.95 & 4.5 & 45.4 & 15.4 & 8.9 \\
\hline 99 & 13.7 & 13.6 & 26.8 & 0.3 & 8.7 \\
\hline 100 & 180 & 7.3 & 32.5 & 4.1 & 8.8 \\
\hline 101 & 50.6 & 10.7 & 29.4 & 8.9 & 8.8 \\
\hline 102 & 1680 & 1.7 & 40.0 & 2.0 & 7.7 \\
\hline 103 & 606 & 0.4 & 45.0 & 9.0 & 6.7 \\
\hline 104 & 25.7 & 11.0 & 38.7 & 0.0 & 6.9 \\
\hline 105 & 1480 & 1.0 & 46.1 & 5.3 & 7.4 \\
\hline 106 & 174 & 2.4 & 94.7 & 0.0 & 6.1 \\
\hline 107 & 542 & 2.8 & 95.1 & 0.0 & 6.3 \\
\hline 108 & 140 & 4.3 & 86.7 & 0.2 & 5.5 \\
\hline 109 & 170 & 5.8 & 77.6 & 0.1 & 3.5 \\
\hline 110 & 11.8 & 7.0 & 17.3 & 0.0 & 3.6 \\
\hline 111 & 54.1 & 5.4 & 61.0 & 0.0 & 3.6 \\
\hline 112 & 36.0 & 6.3 & 15.3 & 2.5 & 4.5 \\
\hline 113 & 358 & 2.4 & 18.5 & 2.6 & 4.8 \\
\hline 114 & 289 & 1.8 & 35.4 & 18.1 & 5.9 \\
\hline 115 & 8.01 & 39.0 & 22.4 & 0.8 & 7.2 \\
\hline 116 & 371 & 2.7 & 35.5 & 5.9 & 7.8 \\
\hline 117 & 10.1 & 43.4 & 16.1 & 1.0 & 8.4 \\
\hline 118 & 3.87 & 12.9 & 30.1 & 2.1 & 8.1 \\
\hline 119 & 239 & 2.8 & 29.8 & 7.5 & 8.1 \\
\hline 120 & 1.46 & 11.8 & 27.7 & 0.0 & 8.1 \\
\hline 121 & 523 & 2.1 & 44.9 & 2.6 & 7.8 \\
\hline 122 & 261 & 3.3 & 27.3 & 7.5 & 6.1 \\
\hline 123 & 8.28 & 5.5 & 36.0 & 25.6 & 6.6 \\
\hline 124 & 1030 & 2.9 & 21.1 & 6.1 & 5.7 \\
\hline 125 & 18.9 & 14.1 & 20.2 & 0.5 & 5.2 \\
\hline 126 & 57.1 & 6.3 & 29.4 & 0.2 & 5.6 \\
\hline 127 & 870 & 1.5 & 23.3 & 1.1 & 5.9 \\
\hline 128 & 434 & 1.2 & 25.4 & 10.7 & 5.4 \\
\hline 129 & 20.1 & 14.8 & 15.0 & 0.1 & 6.0 \\
\hline 130 & 193 & 2.1 & 28.2 & 4.6 & 6.2 \\
\hline 131 & 1.31 & 23.2 & 19.1 & 0.0 & 6.6 \\
\hline 132 & 45.0 & 8.2 & 29.7 & 0.0 & 6.5 \\
\hline 133 & 432 & 4.0 & 27.4 & 2.0 & 5.8 \\
\hline 134 & 119 & 4.0 & 14.1 & 1.9 & 4.9 \\
\hline 135 & 7.11 & 16.1 & 4.8 & 0.0 & 4.7 \\
\hline
\end{tabular}


Table 2.--Basin characteristics for streamflow gaging stations.

$\left[\mathrm{mi}^{2}\right.$, square miles; $\mathrm{ft} / \mathrm{mi}$, feet per mile; in., inches; in./yr, inches per year]

\begin{tabular}{|c|c|c|c|c|c|}
\hline $\begin{array}{l}\text { Site number } \\
\text { (figure } 1 \text { ) }\end{array}$ & $\begin{array}{l}\text { Drainage } \\
\text { area }\end{array}$ & $\begin{array}{l}\text { Main-channel } \\
\text { slope }\end{array}$ & $\begin{array}{c}\text { Storage } \\
\text { (percentage of } \\
\text { drainage area) }\end{array}$ & $\begin{array}{c}\text { Lake } \\
\text { (percentage of } \\
\text { drainage area) }\end{array}$ & $\begin{array}{c}\text { Mean annual runoff } \\
\text { (in./yr) }\end{array}$ \\
\hline 136 & 0.26 & 77.5 & 1.0 & 0.0 & 4.8 \\
\hline 137 & 1030 & 2.5 & 16.9 & 4.2 & 5.4 \\
\hline 138 & 3.89 & 7.4 & 24.3 & 0.0 & 5.2 \\
\hline 139 & 14.5 & 16.1 & 23.0 & 1.4 & 5.2 \\
\hline 140 & 45.6 & 13.0 & 21.9 & 0.6 & 5.3 \\
\hline 141 & 78.8 & 10.4 & 17.3 & 2.5 & 4.9 \\
\hline 142 & 3.09 & 23.4 & 10.1 & 0.0 & 5.5 \\
\hline 143 & 2.63 & 9.6 & 20.7 & 0.0 & 6.0 \\
\hline 144 & 559 & 3.1 & 20.7 & 1.3 & 5.5 \\
\hline 145 & 213 & 4.2 & 16.8 & 0.9 & 4.4 \\
\hline 146 & 0.49 & 44.4 & 8.4 & 0.0 & 4.4 \\
\hline 147 & 243 & 4.5 & 16.9 & 0.8 & 4.5 \\
\hline 148 & 163 & 3.6 & 30.7 & 10.6 & 4.1 \\
\hline 149 & 779 & 3.4 & 20.5 & 4.7 & 4.6 \\
\hline 150 & 8.83 & 4.8 & 28.6 & 7.7 & 5.0 \\
\hline 151 & 240 & 2.4 & 14.2 & 6.2 & 4.0 \\
\hline 152 & 31.3 & 3.2 & 14.4 & 1.7 & 4.7 \\
\hline 153 & 1.09 & 17.5 & 2.4 & 0.0 & 4.7 \\
\hline 154 & 9.24 & 3.5 & 16.2 & 8.8 & 4.2 \\
\hline 155 & 373 & 2.1 & 7.7 & 1.5 & 4.5 \\
\hline 156 & 1160 & 1.8 & 11.7 & 3.2 & 4.9 \\
\hline 157 & 2640 & 2.7 & 17.4 & 4.6 & 5.2 \\
\hline 158 & 8.83 & 11.0 & 24.8 & 12.8 & 5.3 \\
\hline 159 & 0.54 & 36.3 & 21.0 & 0.0 & 7.8 \\
\hline 160 & 4.73 & 9.8 & 33.1 & 0.0 & 7.6 \\
\hline 161 & 2.33 & 13.1 & 29.4 & 0.0 & 7.6 \\
\hline 162 & 1.34 & 34.5 & 14.9 & 0.0 & 7.2 \\
\hline 163 & 86.0 & 8.2 & 22.9 & 1.9 & 5.3 \\
\hline 164 & 128 & 0.9 & 36.6 & 22.8 & 5.5 \\
\hline 165 & 438 & 5.0 & 3.8 & 1.0 & 1.3 \\
\hline 166 & 398 & 7.3 & 2.4 & 1.4 & 1.1 \\
\hline 167 & 459 & 15.0 & 3.3 & 1.7 & 1.2 \\
\hline 168 & 864 & 2.1 & 12.0 & 7.6 & 1.9 \\
\hline 169 & 2.95 & 55.2 & 2.7 & 0.0 & 1.3 \\
\hline 170 & 960 & 4.9 & 3.7 & 1.1 & 2.1 \\
\hline 171 & 0.4 & 7.9 & 5.8 & 0.0 & 2.4 \\
\hline 172 & 96.2 & 6.5 & 17.7 & 11.1 & 3.3 \\
\hline 173 & 0.57 & 53.5 & 0.5 & 0.0 & 3.3 \\
\hline 174 & 7.24 & 38.1 & 3.6 & 0.3 & 3.1 \\
\hline 175 & 308 & 4.0 & 9.9 & 4.1 & 2.8 \\
\hline 176 & 1880 & 3.0 & 12.5 & 5.5 & 2.4 \\
\hline 177 & 2050 & 2.9 & 11.6 & 5.1 & 2.4 \\
\hline 178 & 15.8 & 5.7 & 1.7 & 0.0 & 2.6 \\
\hline 179 & 14.7 & 8.5 & 2.4 & 0.8 & 1.3 \\
\hline 180 & 0.33 & 84.6 & 0.0 & 0.0 & 1.4 \\
\hline
\end{tabular}


Table 2.--Basin characteristics for streamflow gaging stations.

[mi ${ }^{2}$, square miles; $\mathrm{ft} / \mathrm{mi}$, feet per mile; in., inches; in./yr, inches per year]

\begin{tabular}{|c|c|c|c|c|c|}
\hline $\begin{array}{l}\text { Site number } \\
\text { (figure 1) }\end{array}$ & $\begin{array}{l}\text { Drainage } \\
\text { area }\end{array}$ & $\begin{array}{l}\text { Main-channel } \\
\text { slope }\end{array}$ & $\begin{array}{c}\text { Storage } \\
\text { (percentage of } \\
\text { drainage area) }\end{array}$ & $\begin{array}{c}\text { Lake } \\
\text { (percentage of } \\
\text { drainage area) }\end{array}$ & $\begin{array}{l}\text { Mean annual runoff } \\
\text { (in./yr) }\end{array}$ \\
\hline 181 & 3.72 & 29.9 & 0.6 & 0.0 & 1.4 \\
\hline 182 & 115 & 12.3 & 2.7 & 0.9 & 2.0 \\
\hline 183 & 664 & 8.4 & 2.3 & 0.9 & 3.0 \\
\hline 184 & 0.83 & 15.6 & 0.0 & 0.0 & 3.6 \\
\hline 185 & 315 & 2.5 & 6.6 & 3.6 & 3.1 \\
\hline 186 & 6.43 & 23.3 & 0.1 & 0.0 & 1.9 \\
\hline 187 & 259 & 9.4 & 4.4 & 2.9 & 2.4 \\
\hline 188 & 5.56 & 11.6 & 0.9 & 0.0 & 2.5 \\
\hline 189 & 629 & 7.0 & 2.7 & 1.6 & 3.5 \\
\hline 190 & 8.75 & 4.3 & 6.8 & 1.0 & 3.7 \\
\hline 191 & 191 & 3.6 & 0.9 & 0.1 & 3.7 \\
\hline 192 & 4.13 & 7.7 & 0.0 & 0.0 & 3.9 \\
\hline 193 & 32.8 & 2.7 & 0.0 & 0.0 & 3.9 \\
\hline 194 & 0.9 & 34.8 & 0.0 & 0.0 & 2.2 \\
\hline 195 & 0.47 & 54.9 & 0.0 & 0.0 & 2.7 \\
\hline 196 & 3.16 & 47.2 & 0.0 & 0.0 & 3.6 \\
\hline 197 & 0.38 & 44.2 & 0.1 & 0.1 & 3.7 \\
\hline 198 & 777 & 6.0 & 1.5 & 0.7 & 3.7 \\
\hline 199 & 1300 & 4.8 & 1.6 & 0.6 & 4.2 \\
\hline 200 & 170 & 6.9 & 2.7 & 0.5 & 4.2 \\
\hline 201 & 30.2 & 12.9 & 0.2 & 0.0 & 5.8 \\
\hline 202 & 2.34 & 26.3 & 0.0 & 0.0 & 6.1 \\
\hline 203 & 120 & 5.8 & 4.6 & 2.6 & 5.6 \\
\hline 204 & 9.66 & 9.1 & 0.0 & 0.0 & 4.9 \\
\hline 205 & 13.5 & 14.6 & 2.0 & 0.6 & 3.7 \\
\hline 206 & 107 & 6.3 & 2.5 & 1.9 & 4.2 \\
\hline 207 & 843 & 5.1 & 2.5 & 1.4 & 4.4 \\
\hline 208 & 851 & 4.9 & 2.5 & 1.4 & 4.4 \\
\hline 209 & 2410 & 2.2 & 2.0 & 1.3 & 4.5 \\
\hline 210 & 0.06 & 103 & 0.0 & 0.0 & 4.8 \\
\hline 211 & 8.21 & 7.9 & 0.0 & 0.0 & 4.9 \\
\hline 212 & 5.74 & 10.0 & 0.1 & 0.0 & 4.8 \\
\hline 213 & 19.0 & 9.6 & 0.7 & 0.2 & 4.6 \\
\hline 214 & 338 & 2.7 & 3.0 & 2.2 & 4.7 \\
\hline 215 & 1110 & 4.1 & 4.2 & 2.3 & 4.6 \\
\hline 216 & 0.23 & 219 & 0.0 & 0.0 & 4.6 \\
\hline 217 & 67.3 & 3.5 & 0.3 & 0.0 & 4.3 \\
\hline 218 & 238 & 3.5 & 3.9 & 2.3 & 4.6 \\
\hline 219 & 0.35 & 75.3 & 0.0 & 0.0 & 5.6 \\
\hline 220 & 3.18 & 13.8 & 17.4 & 0.1 & 5.5 \\
\hline 221 & 62.2 & 2.3 & 12.5 & 4.7 & 5.4 \\
\hline 222 & 22.2 & 10.5 & 5.7 & 1.0 & 5.3 \\
\hline 223 & 2.76 & 17.1 & 0.7 & 0.0 & 5.2 \\
\hline 224 & 27.2 & 8.3 & 13.2 & 5.0 & 5.5 \\
\hline 225 & 45.4 & 7.7 & 9.9 & 5.3 & 5.7 \\
\hline
\end{tabular}


Table 2.--Basin characteristics for streamflow gaging stations.

$\left[\mathrm{mi}^{2}\right.$, square miles; $\mathrm{ft} / \mathrm{mi}$, feet per mile; in., inches; in./yr, inches per year]

\begin{tabular}{|c|c|c|c|c|c|}
\hline $\begin{array}{l}\text { Site number } \\
\text { (figure 1) }\end{array}$ & $\begin{array}{l}\text { Drainage } \\
\text { area }\end{array}$ & $\begin{array}{l}\text { Main-channel } \\
\text { slope }\end{array}$ & $\begin{array}{c}\text { Storage } \\
\text { (percentage of } \\
\text { drainage area) }\end{array}$ & $\begin{array}{c}\text { Lake } \\
\text { (percentage of } \\
\text { drainage area) }\end{array}$ & $\begin{array}{c}\text { Mean annual runoff } \\
\text { (in./yr) }\end{array}$ \\
\hline 226 & 94.4 & 12.1 & 31.6 & 1.0 & 11.0 \\
\hline 227 & 27.0 & 12.2 & 43.5 & 0.0 & 9.6 \\
\hline 228 & 1.45 & 25.5 & 20.6 & 0.0 & 9.6 \\
\hline 229 & 4.02 & 8.6 & 16.0 & 0.0 & 10.0 \\
\hline 230 & 0.55 & 24.2 & 18.7 & 0.0 & 10.0 \\
\hline 231 & 868 & 5.9 & 35.7 & 1.6 & 10.0 \\
\hline 232 & 4.12 & 22.9 & 26.7 & 0.0 & 9.6 \\
\hline 233 & 974 & 4.4 & 30.6 & 1.2 & 9.2 \\
\hline 234 & 47.3 & 2.8 & 33.7 & 5.2 & 7.5 \\
\hline 235 & 163 & 2.2 & 38.9 & 7.1 & 6.7 \\
\hline 236 & 129 & 8.2 & 11.6 & 1.3 & 5.9 \\
\hline 237 & 15.5 & 6.8 & 0.5 & 0.0 & 5.9 \\
\hline 238 & 87.9 & 1.9 & 20.7 & 6.5 & 5.5 \\
\hline 239 & 1.26 & 35.6 & 1.3 & 0.0 & 6.5 \\
\hline 240 & 5.0 & 15.3 & 0.2 & 0.0 & 6.5 \\
\hline 241 & 435 & 3.4 & 4.0 & 0.6 & 6.3 \\
\hline 242 & 929 & 4.2 & 9.6 & 3.4 & 6.0 \\
\hline 243 & 2.12 & 49.2 & 2.2 & 0.0 & 6.1 \\
\hline 244 & 20.5 & 12.6 & 0.8 & 0.0 & 6.0 \\
\hline 245 & 1340 & 4.9 & 8.1 & 2.6 & 5.9 \\
\hline 246 & 0.07 & 193 & 0.0 & 0.0 & 5.9 \\
\hline 247 & 155 & 7.4 & 4.1 & 0.1 & 6.6 \\
\hline 248 & 78.8 & 17.6 & 2.9 & 0.0 & 6.6 \\
\hline 249 & 17.7 & 26.1 & 2.6 & 0.0 & 6.5 \\
\hline 250 & 38.2 & 14.3 & 1.7 & 0.1 & 6.6 \\
\hline 251 & 22.1 & 5.2 & 0.7 & 0.0 & 6.5 \\
\hline 252 & 0.11 & 152 & 0.0 & 0.0 & 6.2 \\
\hline 253 & 10.0 & 18.9 & 1.5 & 0.0 & 6.2 \\
\hline 254 & 0.37 & 88.3 & 1.3 & 0.0 & 6.0 \\
\hline 255 & 1150 & 6.8 & 2.4 & 0.2 & 6.0 \\
\hline 256 & 4.44 & 44.0 & 0.0 & 0.0 & 5.9 \\
\hline 257 & 1340 & 5.7 & 2.2 & 0.2 & 5.5 \\
\hline 258 & 101 & 11.3 & 1.2 & 0.0 & 5.8 \\
\hline 259 & 77.4 & 15.9 & 1.2 & 0.0 & 5.7 \\
\hline 260 & 271 & 12.1 & 1.8 & 0.0 & 5.5 \\
\hline 261 & 5.02 & 91.7 & 0.4 & 0.0 & 5.5 \\
\hline 262 & 9.04 & 84.7 & 0.3 & 0.0 & 6.1 \\
\hline 263 & 0.74 & 50.1 & 2.3 & 0.0 & 7.1 \\
\hline 264 & 2.39 & 71.3 & 0.3 & 0.0 & 6.9 \\
\hline 265 & 22.6 & 49.8 & 0.8 & 0.0 & 7.0 \\
\hline 266 & 14.1 & 13.1 & 2.9 & 0.0 & 7.0 \\
\hline 267 & 615 & 5.8 & 1.5 & 0.0 & 7.4 \\
\hline 268 & 3.86 & 18.6 & 0.3 & 0.0 & 7.6 \\
\hline 269 & 0.09 & 237 & 0.0 & 0.0 & 7.5 \\
\hline 270 & 7.78 & 73.7 & 0.2 & 0.0 & 7.6 \\
\hline
\end{tabular}


Table 2.--Basin characteristics for streamflow gaging stations.

$\left[\mathrm{mi}^{2}\right.$, square miles; $\mathrm{ft} / \mathrm{mi}$, feet per mile; in., inches; in./yr, inches per year]

\begin{tabular}{|c|c|c|c|c|c|}
\hline $\begin{array}{l}\text { Site number } \\
\text { (figure 1) }\end{array}$ & $\begin{array}{l}\text { Drainage } \\
\text { area }\end{array}$ & $\begin{array}{l}\text { Main-channel } \\
\text { slope }\end{array}$ & $\begin{array}{c}\text { Storage } \\
\text { (percentage of } \\
\text { drainage area) }\end{array}$ & $\begin{array}{c}\text { Lake } \\
\text { (percentage of } \\
\text { drainage area) }\end{array}$ & $\begin{array}{l}\text { Mean annual runoff } \\
\text { (in./yr) }\end{array}$ \\
\hline 271 & 0.15 & 82.9 & 0.0 & 0.0 & 7.1 \\
\hline 272 & 992 & 5.6 & 1.4 & 0.0 & 7.5 \\
\hline 273 & 28.2 & 16.1 & 0.2 & 0.0 & 7.0 \\
\hline 274 & 132 & 20.1 & 0.4 & 0.0 & 7.2 \\
\hline 275 & 1250 & 6.2 & 1.3 & 0.0 & 8.4 \\
\hline 276 & 275 & 10.6 & 0.4 & 0.0 & 8.5 \\
\hline 277 & 1540 & 6.2 & 1.2 & 0.0 & 8.6 \\
\hline 278 & 44.8 & 44.4 & 0.7 & 0.1 & 8.8 \\
\hline 279 & 399 & 3.1 & 2.3 & 0.7 & 6.9 \\
\hline 280 & 1.13 & 38.0 & 2.3 & 0.0 & 7.0 \\
\hline 281 & 45.8 & 10.4 & 2.7 & 0.0 & 6.9 \\
\hline 282 & 28.7 & 6.5 & 0.5 & 0.0 & 6.5 \\
\hline 283 & 5.01 & 25.9 & 3.7 & 2.3 & 2.7 \\
\hline 284 & 2.22 & 35.4 & 0.6 & 0.0 & 2.7 \\
\hline 285 & 3.29 & 24.0 & 0.1 & 0.0 & 3.8 \\
\hline 286 & 1.45 & 20.3 & 3.8 & 0.0 & 3.9 \\
\hline 287 & 5.1 & 13.5 & 0.3 & 0.0 & 3.9 \\
\hline 288 & 1250 & 2.6 & 5.3 & 2.3 & 4.0 \\
\hline 289 & 6.15 & 42.6 & 0.5 & 0.0 & 4.0 \\
\hline 290 & 25.8 & 9.2 & 0.7 & 0.0 & 4.0 \\
\hline 291 & 15.4 & 14.0 & 0.1 & 0.0 & 4.2 \\
\hline 292 & 128 & 4.7 & 1.7 & 0.8 & 4.2 \\
\hline 293 & 65.8 & 6.8 & 1.9 & 0.2 & 1.0 \\
\hline 294 & 0.26 & 53.2 & 0.0 & 0.0 & 1.0 \\
\hline 295 & 6.61 & 26.6 & 0.3 & 0.0 & 1.0 \\
\hline 296 & 1.56 & 55.6 & 0.1 & 0.0 & 1.0 \\
\hline 297 & 110 & 5.6 & 5.7 & 2.4 & 1.0 \\
\hline 298 & 74.5 & 27.7 & 1.2 & 0.0 & 1.0 \\
\hline 299 & 164 & 4.8 & 5.0 & 1.2 & 1.0 \\
\hline 300 & 25.2 & 24.8 & 1.1 & 0.0 & 1.0 \\
\hline 301 & 48.3 & 18.1 & 0.8 & 0.0 & 1.0 \\
\hline 302 & 0.33 & 54.2 & 0.0 & 0.0 & 1.1 \\
\hline 303 & 9.78 & 23.4 & 0.4 & 0.0 & 1.1 \\
\hline 304 & 54.0 & 14.6 & 1.0 & 0.0 & 1.1 \\
\hline 305 & 4.04 & 47.4 & 0.5 & 0.0 & 1.1 \\
\hline 306 & 200 & 6.3 & 1.8 & 0.0 & 1.1 \\
\hline 307 & 63.2 & 15.9 & 0.8 & 0.0 & 1.3 \\
\hline 308 & 100 & 6.1 & 2.0 & 0.0 & 1.4 \\
\hline 309 & 1.03 & 31.6 & 0.0 & 0.0 & 1.0 \\
\hline 310 & 2.16 & 49.5 & 0.9 & 0.0 & 1.2 \\
\hline 311 & 475 & 5.5 & 1.3 & 0.0 & 1.3 \\
\hline 312 & 0.31 & 122 & 0.0 & 0.0 & 1.2 \\
\hline 313 & 57.3 & 6.5 & 2.6 & 0.0 & 2.1 \\
\hline 314 & 2.52 & 24.1 & 1.0 & 0.0 & 1.7 \\
\hline 315 & 0.2 & 105 & 0.0 & 0.0 & 1.7 \\
\hline
\end{tabular}


Table 2.--Basin characteristics for streamflow gaging stations.

$\left[\mathrm{mi}^{2}\right.$, square miles; $\mathrm{ft} / \mathrm{mi}$, feet per mile; in., inches; in./yr, inches per year]

\begin{tabular}{cccccc}
\hline $\begin{array}{c}\text { Site number } \\
\text { (figure 1) }\end{array}$ & $\begin{array}{c}\text { Drainage } \\
\text { area }\end{array}$ & $\begin{array}{c}\text { Main-channel } \\
\text { slope }\end{array}$ & $\begin{array}{c}\text { Storage } \\
\text { (percentage of } \\
\text { drainage area) }\end{array}$ & $\begin{array}{c}\text { Lake } \\
\text { (percentage of } \\
\text { drainage area) }\end{array}$ & $\begin{array}{c}\text { Mean annual runoff } \\
\text { (in./yr) }\end{array}$ \\
\hline 316 & 419 & 4.1 & 1.7 & 0.0 & 1.8 \\
317 & 0.22 & 94.3 & 0.0 & 0.0 & 1.8 \\
318 & 0.15 & 65.2 & 0.0 & 0.0 & 2.5 \\
319 & 2.13 & 30.8 & 1.5 & 0.0 & 2.7 \\
320 & 790 & 4.0 & 1.5 & 0.0 & 2.0 \\
321 & 89.2 & 6.9 & 0.7 & 0.1 & 3.3 \\
322 & 267 & 4.8 & 0.4 & 0.0 & 2.8 \\
323 & 180 & 4.4 & 0.4 & 0.0 & 2.3 \\
324 & 15.6 & 6.5 & 2.6 & 0.0 & 3.7 \\
325 & 7.63 & 5.4 & 0.1 & 0.0 & 3.8 \\
326 & 2.67 & 13.9 & 0.8 & 0.0 & 3.7 \\
327 & 40.5 & 5.8 & 1.3 & 0.0 & 3.8 \\
328 & 22.4 & 8.2 & 0.0 & 0.0 & 4.0 \\
\hline
\end{tabular}


This program computes estimates of 2-, 5-, 10-, 25-, 50-, and 100-year peak flows for ungaged sites in Minnesota based on either a Regional Regression Equation (RRE) method or a Region of Influence (ROI) method. (see the report "Techniques for Estimating Peak Flow on Small Streams in Minnesota" by Loren Carlson, and Sanocki, USGS water Resources Investigations Report 97-

* No warranty, expressed or implied, is made by the

* USGS as to the accuracy and functioning of this

* program and related program material.

ENTER name of output file

\section{output}

Use regional regression equations (RRE)

or region of influence method? (ROI)

\section{rre}

ENTER site id

Judicial Ditch 11

ENTER region where site is located:

$\begin{array}{llllll}A & B & C & D & E & F\end{array}$

d

ENTER basin characteristics for site

Drainage area (sq. mi.)

15.0

Main-channel slope (ft./mi.)

2.6

Lakes percent area + 1

\section{0}

Flood frequency estimates for

Judicial Ditch 11

Region D

RECURR. PEAK FLOW

INTERVAL (CFS)

2

95.

$\operatorname{SEP}(\%) \quad E Q$. YRS.

$90 \%$ PRED. INTERVAL

$5 \quad 191$.

$10 \quad 271$.

389 .

46 .

5.18

42 .

212.

$\begin{array}{ll}25 & 389 . \\ 50 & 487 .\end{array}$

47.

6.78

92 .

397.

50 .

129.

570 .

587.

54 .

8.38

177.

855 .

100

57.

9.20

212 .

1120 .

Do you want to perform another analysis ( $y$ or $n$ )?

$\mathbf{y}$

Use regional regression equations (RRE)

or region of influence method? (ROI)

\section{roi}

ENTER indentifer for ungaged site

Judicial Ditch 11

ENTER basin characteristics for site

Drainage area (sq. mi.)

15.0

Main-channel slope (ft./mi.)

2.6

Storage percent +1

1.0

Lakes percent area + 1

1.0

Generalized runoff 


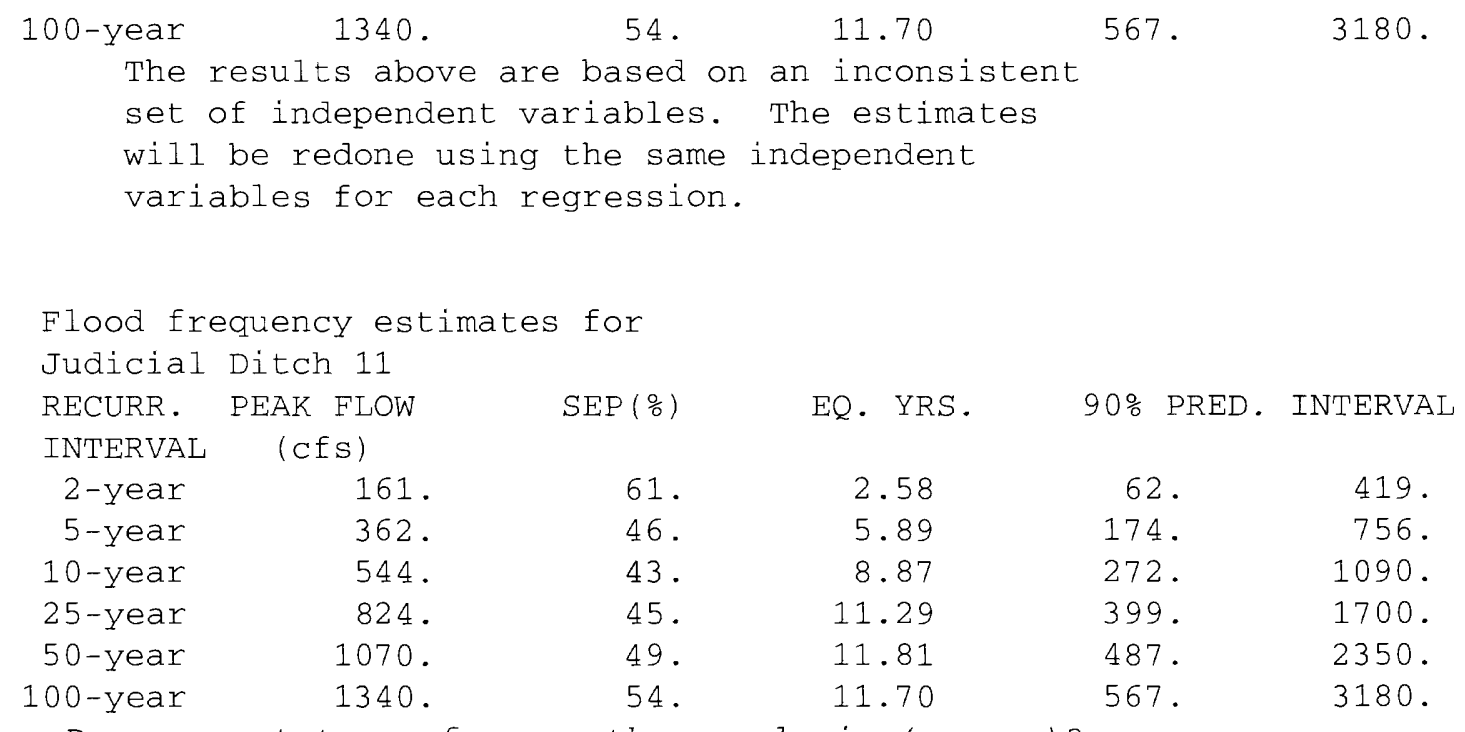

Do you want to perform another analysis ( $y$ or $n)$ ?

$\mathbf{n}$ 
REGION OF INFLUENCE ANALYSIS OF PEAK FLOW DATA FOR SITE Judicial Ditch 11

Basin characteristic data:

$\begin{array}{ll}\text { Drainage area (sq. mi.) } & 15.00000 \\ \text { Main channel slope (ft./mi.) } & 2.600000 \\ \text { Storage percent }+1 & 1.000000 \\ \text { Lakes percent area +1 } & 1.000000 \\ \text { Generalized runoff (in./yr) } & 4.000000\end{array}$

STEP 1 regression coefficients:

$\begin{array}{lrrrr}\text { Variable } & \text { Coefficient } & \text { Standard error } & \text { T for Ho:beta=0 } & \text { Prob>lTI } \\ \text { Constant } & 0.61422 & 0.38234 & 1.60648 & \\ \log (\mathrm{DA}) & 0.75374 & 0.04108 & 18.34867 & 0.0001 \\ \log (\mathrm{SL}) & 0.42451 & 0.11144 & 3.80943 & 0.0006 \\ \log (\mathrm{ST}) & -0.26657 & 0.11679 & -2.28255 & 0.0297 \\ \log (\mathrm{LK}) & -0.04523 & 0.17081 & -0.26482 & 0.7930 \\ \log (\mathrm{RO}) & 0.73404 & 0.56706 & 1.29446 & 0.2054\end{array}$

Deleting variable: $\log (\mathrm{LK}), \mathrm{T}$-score less than 1.7.

STEP 2 regression coefficients:

$\begin{array}{lrrrr}\text { Variable } & \text { Coefficient } & \text { Standard error } & \text { T for HO:beta=0 } & \text { Prob>lTI } \\ \text { Constant } & 0.59563 & 0.37027 & 1.60865 & \\ \log (\mathrm{DA}) & 0.75285 & 0.04045 & 18.61240 & 0.0001 \\ \log (\mathrm{SL}) & 0.42856 & 0.10836 & 3.95498 & 0.0004 \\ \log (\mathrm{ST}) & -0.28958 & 0.07753 & -3.73509 & 0.0008 \\ \log (\mathrm{RO}) & 0.76109 & 0.55065 & 1.38217 & 0.1768\end{array}$

Deleting variable: $\log (\mathrm{RO}), \mathrm{T}$-score less than 1.7 .

Final regression statistics for Judicial Ditch 11 2 -year peak

Regression coefficients:

\begin{tabular}{|c|c|c|c|c|}
\hline Variable & Coefficient & Standard error & $\mathrm{T}$ for $\mathrm{HO}:$ beta $=0$ & Probs $>\mathrm{T} \mid$ \\
\hline Constant & 1.04533 & 0.17730 & 5.89592 & \\
\hline $\log (D A)$ & 0.74722 & 0.04074 & 18.33976 & 0.0001 \\
\hline $\log (S L)$ & 0.43872 & 0.10960 & 4.00301 & 0.0003 \\
\hline $\log (\mathrm{ST})$ & -0.25140 & 0.07342 & -3.42397 & 0.0017 \\
\hline
\end{tabular}

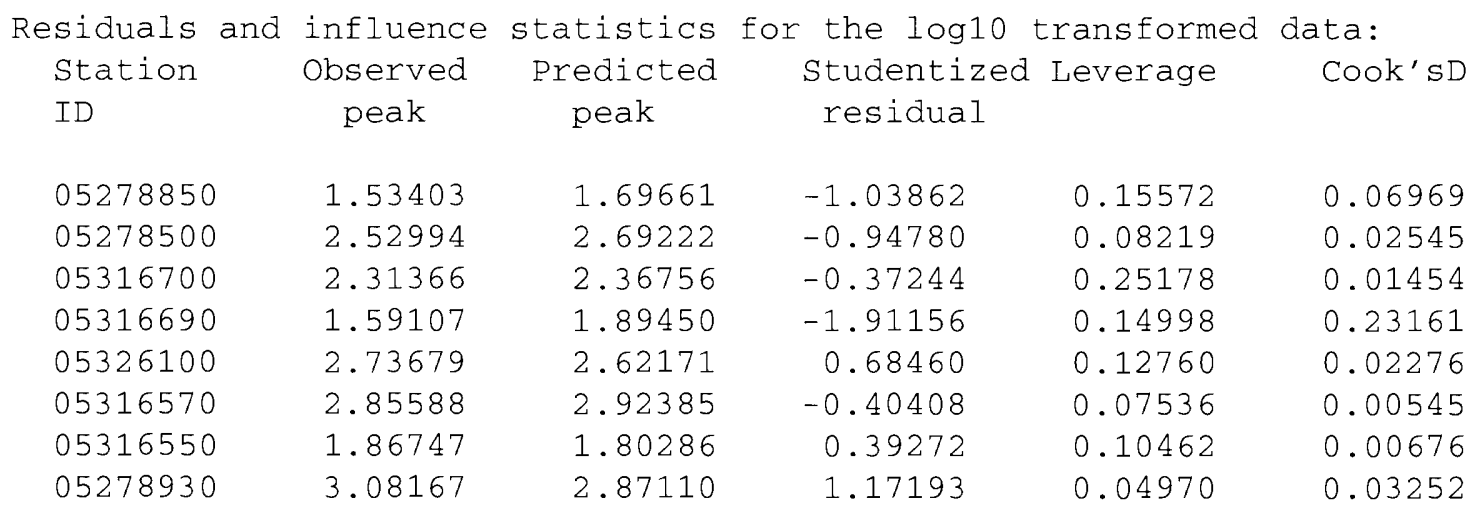




$\begin{array}{lrrrrr}05317000 & 3.50949 & 3.56785 & -0.37756 & 0.12369 & 0.00635 \\ 05313800 & 1.50786 & 1.50831 & -0.00263 & 0.13656 & 0.00000 \\ 05316500 & 3.07159 & 3.36391 & -1.86984 & 0.10661 & 0.13194 \\ 05278750 & 1.45788 & 1.48492 & -0.16629 & 0.08584 & 0.00111 \\ 05278700 & 2.05231 & 2.08270 & -0.18783 & 0.09886 & 0.00152 \\ 05317200 & 2.70552 & 2.93639 & -1.33240 & 0.03139 & 0.03419 \\ 05327000 & 2.97123 & 2.88720 & 0.48727 & 0.03127 & 0.00464 \\ 05278120 & 3.23216 & 3.10417 & 0.69726 & 0.07755 & 0.01482 \\ 05279000 & 3.33116 & 3.17161 & 1.00557 & 0.09114 & 0.03377 \\ 05316950 & 3.45797 & 3.44627 & 0.07015 & 0.08889 & 0.00018 \\ 05278350 & 1.70501 & 1.68274 & 0.14215 & 0.17099 & 0.00141 \\ 05278000 & 2.30685 & 2.56704 & -1.65283 & 0.12732 & 0.13179 \\ 05325100 & 1.82607 & 1.59528 & 1.22965 & 0.23058 & 0.13022 \\ 05316920 & 1.44871 & 1.44281 & 0.03694 & 0.14487 & 0.00008 \\ 05314500 & 3.18301 & 2.86495 & 1.84783 & 0.05440 & 0.07802 \\ 05313500 & 3.15616 & 3.42916 & -1.76749 & 0.13407 & 0.14438 \\ 05272950 & 2.47129 & 2.59120 & -0.66121 & 0.10833 & 0.01632 \\ 05320000 & 3.79260 & 3.59834 & 1.26334 & 0.13533 & 0.07568 \\ 05276200 & 2.89840 & 2.80096 & 0.57833 & 0.07145 & 0.01011 \\ 05276000 & 2.91180 & 2.74267 & 0.91056 & 0.07334 & 0.01983 \\ 05316900 & 2.12385 & 2.15309 & -0.18230 & 0.13674 & 0.00182 \\ 05319500 & 3.43889 & 3.39870 & 0.24245 & 0.07650 & 0.00180 \\ 05276100 & 1.28103 & 1.29184 & -0.07052 & 0.20479 & 0.00041 \\ 05320500 & 3.62262 & 3.40783 & 1.34446 & 0.08127 & 0.05638 \\ 05319490 & 3.51574 & 3.40371 & 0.43945 & 0.03766 & 0.00253 \\ 05330600 & 1.67210 & 1.85768 & -1.11415 & 0.06887 & 0.04062 \\ 05320200 & 1.28556 & 1.01541 & 1.80840 & 0.23682 & 0.32477 \\ 05330550 & 2.21352 & 2.29238 & -0.46507 & 0.03791 & 0.00456\end{array}$

Mean sampling error variance: 0.0048

Mean model error variance: $\quad 0.0263$

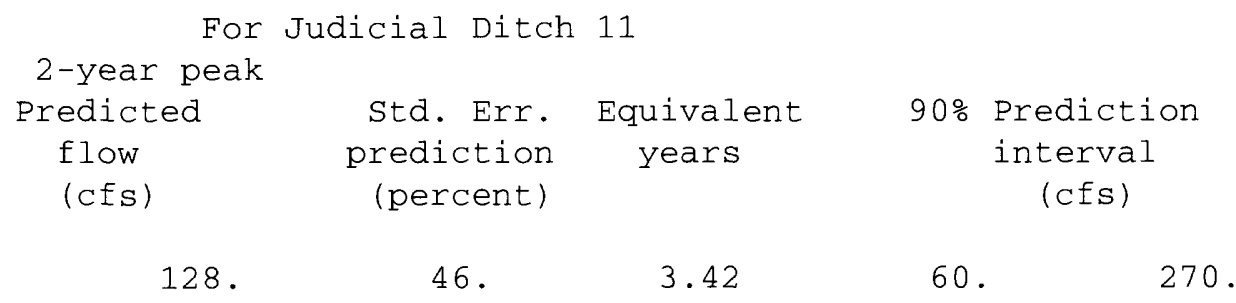

